\title{
Do borrão às aguadas: os engenheiros militares e a representação da Capitania de São Paulo
}

\section{Beatriz Piccolotto Siqueira Bueno}

RESUMO: A análise do papel dos engenheiros militares perpassa as discussões sobre regiões específicas, mesmo quando eles, aparentemente, estão ausentes delas. Sua presença ou ausência sempre foi sinônimo de interesse e de projeto colonizador mais ou menos dirigido. Este ensaio tem como objeto de estudo a cartografia dos engenheiros militares atuantes na Capitania de São Paulo, território comumente visto como economicamente periférico e mais autônomo face aos desígnios da Coroa portuguesa. Com foco no corpus cartográfico de alguns profissionais que aqui atuaram, trata indiretamente da multifacetada atuação desses engenheiros, bem como do processo de feitura das cartas geográficas, corográficas e topográficas, do borrão às aguadas. Investigar a cartografia de alguns desses profissionais permite não apenas explorar a riqueza de suas biografias, como, também, acompanhar o processo de produção técnica dos mapas e os desígnios políticos envolvidos no devassamento e representação das terras descobertas no Novo Mundo.

PALAVRAS-CHAVE: Engenheiros Militares. Cartografia Histórica. América Meridional. Capitania de São Paulo. Séculos XVI-XVIII

ABSTRACT: Analyzing the role of military engineers means venturing into discussions about specific regions, even those from which they are apparently absent. Their presence or absence has always been synonymous with interest and a more or less directed colonization project. This essay examines the maps produced by the military engineers working in the Captaincy of São Paulo, a territory often looked upon as one of little economic import and a rather autonomous area in light of the plans of the Portuguese Crown. By focusing on the cartographic corpus bequeathed by certain professionals serving in this region, we deal indirectly with the multifaceted role of these engineers as well as with the process of making geographic, chorographic and topographic charts - all the way from the sketch to watercolored maps. Perusing the charts constructed by some of these professionals enabled us not only to delve into the rich details of their biographies but also to observe the technical mapmaking process and to unravel the political designs behind the exploration and representation of the lands discovered in the New World. KEYWORDS: Military engineers. Historical cartography. South America. São Paulo Captaincy. $16^{\text {th }}$ - $18^{\text {th }}$ centuries.

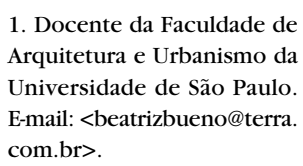

com.br>. 
2. Ver B. P. S. Bueno (2007, p. 29-49).

3. Ver B. P. S. Bueno (ed. rev. 2003). Sobre o tema, ler especialmente Capítulo 1. $\bigcirc$ controle das terras descobertas demandou um novo tipo de profissional2. Embrenhar-se nas terras do novo mundo, mapeá-las e estabelecer sistema de defesa eficiente implicou em novos procedimentos, técnicas e instrumentos. A partir do século XVII, os engenheiros militares roubaram a cena, ofuscando a figura dos cosmógrafos que haviam protagonizado o processo de expansão ultramarina. Os engenheiros militares, especializados em questões de guerra, na fundação de cidades e também no mapeamento de grandes superfícies terrestres, tornaram-se imprescindíveis no processo de conhecimento, ocupação, definição e controle dos territórios descobertos no ultramar. Mais de duas centenas deles atuaram no Brasil entre os séculos XVI e XVIII. É difícil imaginá-los em campo, trabalhando em meio à densa floresta, calor inclemente e insetos. Circulavam em canoas ou no lombo de mulas, transportando instrumentos do porte dos relógios de pêndula, telescópios, quadrantes e teodolitos, bem como uma sofisticada tralha e muitos mantimentos. Nessas condições, eles participaram ativamente do processo de conquista e colonização das Américas portuguesa e espanhola (Figura 1).

As capitanias de São Vicente e de Santo Amaro - convertidas no século XVIII em Capitania de São Paulo - gozaram da presença de alguns engenheiros militares. Longos períodos de ausência foram interrompidos por permanências temporárias, em resposta a demandas geopolíticas estratégicas, vitais para a sobrevivência da Coroa portuguesa em solos meridionais.

$\mathrm{Na}$ longa duração, a trajetória de alguns profissionais em solos paulistas nos dá a medida dos interesses metropolitanos aqui em jogo.

Dimensões hermenêuticas da cartografia

De borrões a mapas aquarelados, de relatórios a projetos jamais executados, a vasta série cartográfica referente à Capitania de São Paulo merece cuidados epistemológicos em sua interpretação. Para a análise dessas fontes visuais falsamente neutras e naturais, é fundamental indagar sobre a natureza do mapa e sobre os desígnios que orientaram a sua feitura, bem como sobre os profissionais envolvidos, os documentos escritos a eles relacionados, os desígnios que cumpriam e os descaminhos entre projeto e prática.

Produtos da ação humana, mapas têm, como documentos históricos, uma natureza social e são, ao mesmo tempo, imagens (representação gráfica) e texto (discurso), desenhos e desígnios (neologismos do séc. XVI, não por acaso originários de uma mesma raiz etimológica) ${ }^{3}$. Para além de duplos da realidade, documentos exclusivamente derivados da ciência e da arte de um dado período, os mapas são uma construção social do mundo expressa por meio da cartografia. $\bigcirc$ que lemos em um mapa está relacionado tanto com fenômenos, vistos e medidos, da paisagem como com um mundo invisível e suas ideologias, escondidas nas entrelinhas do discurso visual, aparentemente neutro. Não são, assim, artefatos objetivos ou exatos, sendo fundamental ao pesquisador explorar 
- nas entrelinhas da imagem - significados, agendas ocultas e visões de mundo. Para além de signos e símbolos - linhas, cores, códigos e convenções de representação - que nos obrigam, de partida, a desconstruir a gramática que orienta a leitura e tradução do texto do mapa Igramática esta compreensível através dos tratados de desenho cartográfico da época) ${ }^{4}$, cumpre-nos interpretar a sua dimensão simbólica, relacionando um artefato cartográfico a outras séries documentais. A estratégia interpretativa deve entender mapa e contexło em estreita relação dialética, indagando sobre o cartógrafo e o contexto de produção, sobre o mapa em meio a outros mapas e outros textos, bem como sobre os desígnios que orientaram a sua feitura, formato, circulação e consumo.

No que diz respeito ao contexto do cartógrafo, um bom ponto de partida é descortinar as intenções e as circunstâncias de quem traçou os mapas, respondendo às indagações de por que, para quem e como foram feitos. Em se tratando de mapas oficiais manuscritos (tal como a maioria das cartas desenhadas por engenheiros militares), a identificação da autoria não é algo tão complexo, embora em geral, ao desenhar um mapa, o cartógrafo não parta do zero,

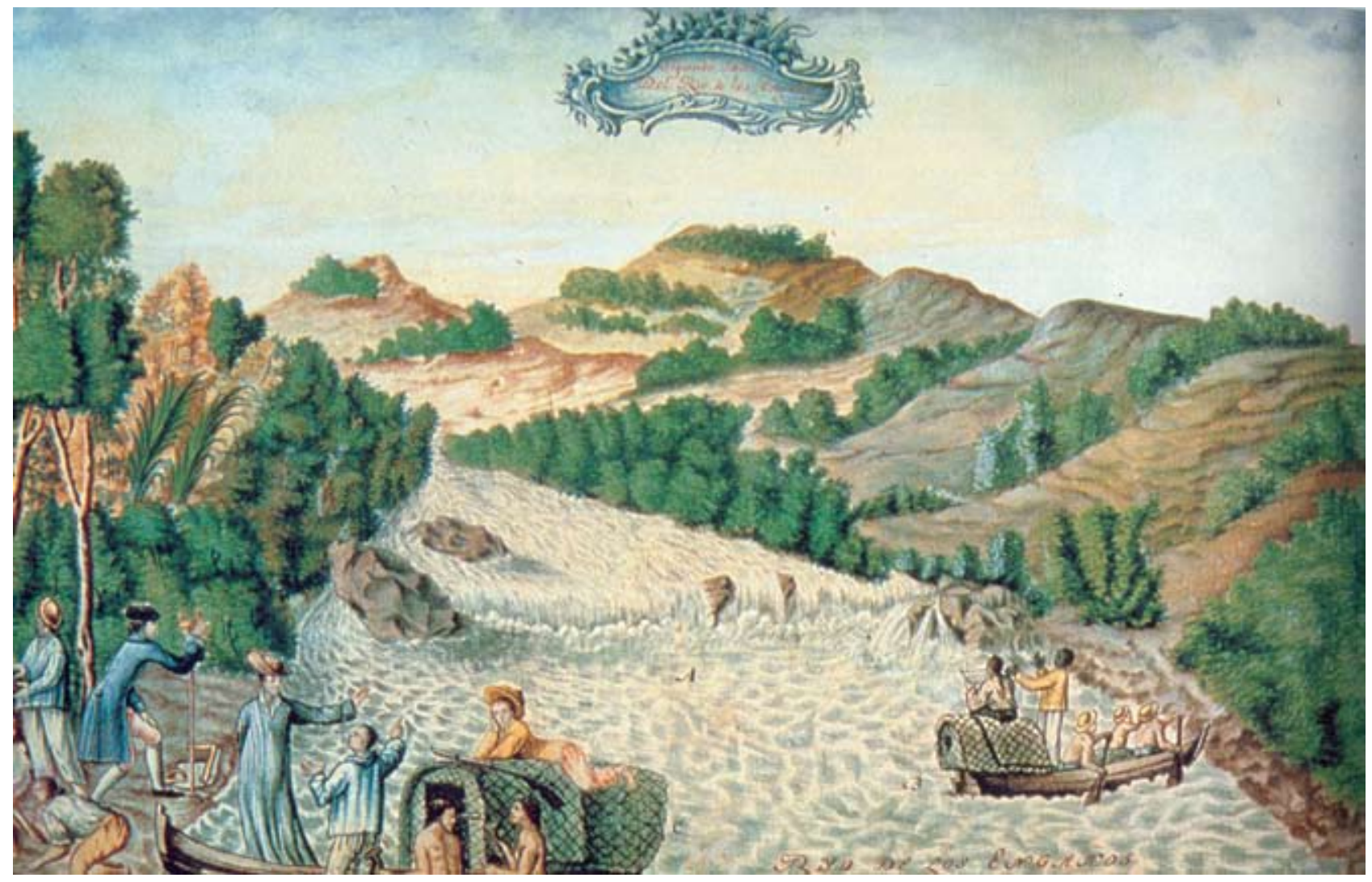

Figura 1 - $\bigcirc$ engenheiro em campo. Aquarela retirada de um conjunto de dez, realizadas provavelmente em 1788, durante as viagens de demarcação ma Amazônia. Francisco Requena y Herrera (1743-1824). Segundo salto del Rio de los Engaños. [1788]. The Oliveira Lima Library/ The Catholic University of America, Washington. 
5. B. P. S. Bueno (ed. rev. 2003). Sobre o tema, ler especialmente Capítulo 3.

6. Ver A J. R. Russell-Wood (1998). valendo-se de outras matrizes, realizando acréscimos sobre bases precedentes. É preciso estar atento à intricada autoria múltipla dos mapas, por vezes até mesmo produto da divisão do trabalho.

Cada mapa deriva de processos que envolvem indivíduos, técnicas e instrumentos, códigos e convenções de representação, trazendo ali amalgamados vários textos. É justamente esta intertextualidade que deve ser descoberta no processo interpretativo. Por outro lado, do borrão às aguadas (i. e. do esboço à versão definitiva), de relatório a projeto, de carta topográfica a carta geográfica, os recortes da realidade (i. e. a escala de representação do mapa) alteram-se em função dos desígnios que cumprem, cabendo ao pesquisador proceder indagações em paralelo ao minucioso exame formal do objeto visual em mãos.

No que diz respeito ao comitente, no caso da cartografia dos engenheiros militares, trata-se de ferramentas de Estado, feitas por profissionais formados em Academias Militares ${ }^{5}$ - instituições do Estado e para servi-lo -, cujo ensino era constantemente atualizado, segundo os padrões cartográficos internacionais de vanguarda, para atender aos desígnios - das coroas europeias - de expansão e conquista de novos territórios. Os mapas geográficos, corográficos, topográficos (de cidades ou de edifícios) eram, em geral, registros administrativos ou projetos de obras novas. Além de sua dimensão pragmática, tratava-se, por vezes, de instrumentos da diplomacia, ou propagandísticos das realizações políticas do Estado, acentuando-se nestes casos sua dimensão retórica. Nesse sentido, a resposta aos desígnios que orientam a feitura de um mapa ou série de mapas permite entrever políticas estatais, limitando, na medida em que alarga a sua dimensão social, a influência individual do próprio cartógrafo.

Se nenhum mapa está hermeticamente fechado em si mesmo, outra pergunta interpretativa fundamental a fazer é: como ele se relaciona com outros mapas e documentos correlatos? Nesse sentido, construir genealogias de mapas é, sem dúvida, outra atitude inevitável por parte do pesquisador. Além disso, dado que eles raramente circularam avulsos, faz-se necessário consultar a respectiva documentação escrita. É neste aspecto que reside um enorme desafio ao pesquisador de mapas oficiais e manuscritos dos engenheiros militares, já que, em muitos arquivos e bibliotecas atuais, a documentação escrita que acompanhava estes desenhos foi separada dos mesmos, o que dificulta, e muito, a investigação contextual da cartografia.

Ora, num vasto império em movimento ${ }^{6}$, essas folhas de papel alinhavaram muitas conversas e determinações - fruto de agendas oficiais explícitas ou ocultas que nos cabe investigar - e foram não só fundamentais para plasmar em instantâneos gráficos esses moventes impérios do Antigo Regime, mas, sobretudo, instrumentos de sua orquestração e gestão: mapas e ofícios circularam juntos, interligando e articulando mundos distantes, seja registrando obras realizadas, seja projetando outras, seja definindo políticas de ocupação e conquista, seja assinalando imperativos territoriais de uma agressiva expansão 
europeia em novos e velhos mundos, seja legitimando-os em acordos políticos internacionais, seja propagandeando feitos.

Para investigar os significados intrínsecos aos mapas - não abordados neste artigo -, recomenda-se a metodologia de Erwin Panofsky ${ }^{7}$ para a análise iconográfica e iconológica das fontes visuais. A análise iconográfica põe luz sobre o tema primário, desconstruindo os diversos níveis da representação gráfica - conteúdo primário, instrumentos e técnicas de registro em campo e no gabinete, códigos e convenções empregados etc.; ao passo que a análise iconológica exacerba um segundo nível de investigação, mergulhando nas entrelinhas retóricas do discurso cartográfico, em busca de um estrato simbólico com conotações ideológicas nem sempre evidentes.

Para além do estudo dos motivos ornamentais de cartuchos e molduras, nesta segunda dimensão hermenêutica está em jogo descortinar metáforas, metonímias e hipérboles visuais, muitas vezes encobertas no uso de símbolos convencionais exacerbados, ênfases gráficas, centralidades criadas, linhas abstratas que registram territórios almejados, distorções intencionais de coordenadas geográficas em prol de interesses territoriais obscuros, ausências propositais de registro ou de topônimos, apagamento de populações que antecediam a presença europeia, vazios propositais, omissões intencionais - o que torna a tarefa de leitura e interpretação de uma mapa algo extremamente instigante e cheio de armadilhas perigosas.

A análise da produção cartográfica dos engenheiros militares perpassa as discussões sobre regiões específicas. Sua presença ou ausência sempre foi sinônimo de interesse e projeto colonizador mais ou menos dirigido. Este ensaio tem como objeto de estudo a cartografia dos engenheiros militares atuantes na Capitania de São Paulo, território comumente visto como economicamente periférico e mais autônomo politicamente em face aos desígnios da Coroa portuguesa. Nesse sentido, cabe indagar quais os profissionais que aqui estiveram e quais os desígnios que orientaram o seu envio e atividades realizadas. Convém lembrar que os engenheiros militares eram caros profissionais do Estado e, dada a vasta dimensão do Brasil, a sua oferta sempre foi inferior à demanda. Nesse sentido, eram deslocados de um lugar a outro, permanecendo temporariamente nas várias capitanias, vinculados sempre a demandas geopolíticas e estratégicas ou a obras de infraestrutura territorial e urbana. São frequentes as queixas da falta de engenheiros por parte dos governadores das diversas capitanias, inclusive nas capitais regionais, como Rio de Janeiro, Salvador, Recife, São Luís e Belém. Em contextos periféricos, permaneciam esporadicamente, cumprindo tarefas breves. Muitas vezes, em sua ausência, governadores, ouvidores e outros funcionários da Coroa tiveram que substituílos, cumprindo papéis de arquitetos, inclusive assinando projetos de fortificações, de arquitetura civil ou realizando mapas. 
8. Assim chamados por serem os profissionais habilitados a desenhar cartas cosmográficas e cartas de marear, os cosmógrafos foram importantes atores na Expansão Ultramarina Portuguesa. Carta Cosmográfica é uma "carta universal, em que o mundo todo está representado". Carta de marear "he a que representa em plano todo o globo da terra, ou parte delle, descrita cõ todos os rumos da agulha de marear. Nela se conhece o tempo dos mares $\&$ em que se vem os penedos, cachopos, bãcos de area, \& outras perigosas paragens do mar. Por ella sabe o piloto, qual o vento ha mister, \& juntamente a altura, que tem o lugar, para onde ha de encaminhar sua não". Cf. R. Bluteau (1712). Nesse período inexistiam os termos cartógrafo e cartografia. O neologismo cartografia foi inventado pelo historiador português Manoel Francisco de Barros e Sousa (1791 1865), II visconde de Santarém, em carta datada de $\mathrm{Pa}$ ris, a 8 de dezembro de 1839 , endereçada a Francisco Adolfo Varnhagen, onde consta: "invento esta palavra, já que aí se tem inventado tantas".

9. Ver D. Mora-Figueroa (1998).

10. Ver B. P. S. Bueno (2005 2007).

11. Convém lembrar que os Teixeira-Albernaz elaboraram atlas e cartas relacionados tanto aos domínios portugueses como aos castelhanos Cf. A. Cámara (1998). Pedro Teixeira, além da Carta ge ral do reino de Portugal (1662), legou-nos El Atlas del Rey Planeta. La Descripcion de España y de las cos tas y puertos de sus reinos (1634). Cf. F. Pereda e F. Marías (2007). Esses personagens mereceriam uma investigação mais acurada e de perspectiva comparada, sobretudo nos tempos da União das Coroas Ibéricas. O estudo dessas biografias permitiria, inclusive, elucidar uma provável origem castelhana do nome Albernaz.
As Relaciones Geographicas de Índias em tempos da União das Coroas Ibéricas (1580-1640)

As primeiras representações do Brasil são fruto de cosmógrafos $^{8}$, atores sociais inicialmente envolvidos na trama do processo de expansão ultramarina, encarregados de documentar as rotas comerciais e os mundos novos descobertos que se ansiava conquistar.

Representações costeiras mais pormenorizadas datam apenas do período da União das Coroas Ibéricas (1580-1640) e derivaram da ação de cosmógrafos e engenheiros militares. Não se restringindo ao Brasil, as Relaciones Topográficas de Castilla y Geográficas de Índias9 foram realizadas com o intuito de pormenorizar aspectos econômicos, políticos e militares das vastas zonas em processo de conquista pelos Áustrias, parte portanto de uma estratégica política de recenseamento do seu amplo império, que nessa época incorporava os domínios portugueses. Os atlas da prestigiosa família dos Teixeira-Albernaz ${ }^{10}$ inserem-se nessa série documental e foram os primeiros a contemplar, em detalhes, o litoral das capitanias de São Vicente e Santo Amaro.

Seu precursor, Luís Teixeira, teve o mérito de percorrer a costa brasileira com o objetivo de atualizar a carta geral e executar cartas locais. $\bigcirc$ Roteiro de todos os sinaes, conhecimemtos, fundos, baixos, Alturas, e derrotas, que ha na Costa do Brasil desdo cabo de Sãto Agostinho até o estreito de Fernão de Magalhães (c. 1586), a ele atribuído, que está na Biblioteca da Ajuda, em Lisboa, constitui o primeiro atlas de toda uma vasta região da América portuguesa, bem como o primeiro fruto de uma expedição, de levantamento da costa, organizada oficialmente com fins científicos. Além de uma carta geral, contendo todo o Brasil dividido em capitanias (Figura 2), inclui doze cartas, contemplando toda a costa, de Olinda à Terra do Fogo. Na carta intitulada "Sam Vicẽte", destacam-se as vilas de São Vicente, Santos, Itanhaém e "S. Amaro" Ina ilha de Santo Amaro, ao que se sabe, jamais existente), bem como menção a "fazendas", "caminho pera o sertaõ", rios, o forte de Santa Cruz de Itapema, protegendo o acesso ao canal do Casqueiro, e as Fortalezas de "Sam Filipe" e "S. Thiago", protegendo o acesso à Barra de Bertioga (Figura 3).

Além do Roteiro de todos os sinaes..., de Luís Teixeira, as capitanias de São Vicente e Santo Amaro contaram com outros levantamentos de mesma natureza, a maioria deles aquarelados e iluminados em Portugal pelo cosmógrafo régio João Teixeira Albernaz l'1 , que, ao contrário do pai, jamais aqui esteve.

Trata-se de uma sequência de relatórios, elaborados in loco, o primeiro deles por Diogo de Campos Moreno, sargento-mor do Brasil. Datado de 1609, jamais passado a limpo e iluminado, intitula-se Relação das praças fortes, povoaçois, e cousas de importancia que Sua Magestade tem na costa do Brazil; fazendo principio dos baixos ou ponta de São Roque para Sul; do estado de defenção dellas, de seus fruttos e rendimentos, feitta pelo sargento-mor desta villa Dioguo de 


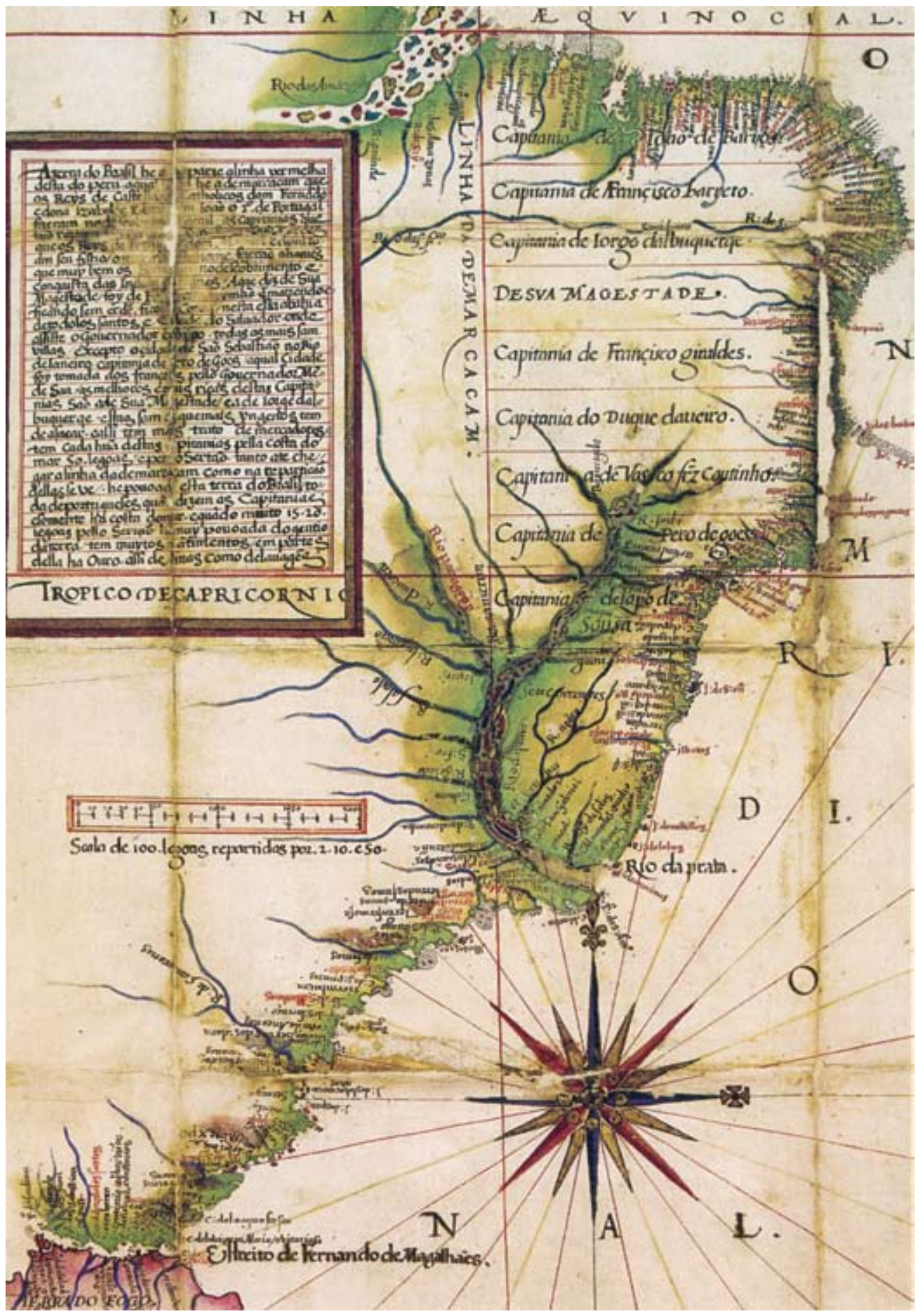

Figura 2 - Carta Geral do Brasil. In: Roteiro de todos os sinaes, conhecimemtos, fundos, baixos, Alturas, e derrotas, que ha na Costa do Brasil desdo cabo de Sãto Agostinho até o estreito de Fernão de Magalhães". Autor: Luís Teixeira. Datável de e c. 1586. Original pertencente à Biblioteca da Ajuda - Lisboa. Reprodução da edição fac-similada do manuscrito. Lisboa: Tagol, 1988. 


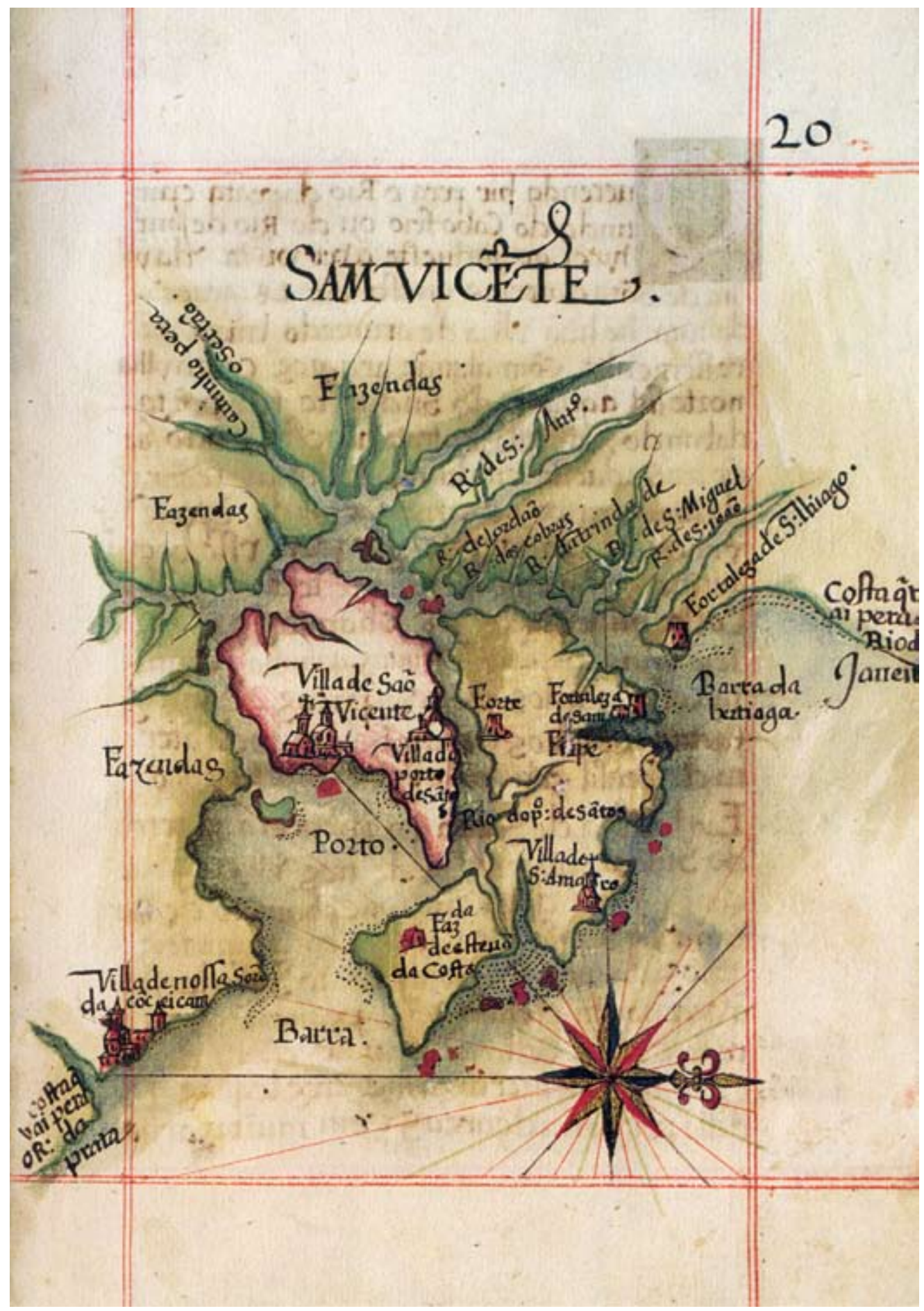

Figura 3 - Sam Vicẽte. In: Roteiro de todos os sinaes, conhecimemtos, fundos, baixos, Alturas, e derrotas, que ha na Costa do Brasil desdo cabo de Sãto Agostinho até o estreito de Fernão de Magalhães". Autor: Luís Teixeira. Datável de e c. 1586. Original pertencente à Biblioteca da Ajuda Lisboa. Reprodução da edição fac-similada do manuscrito. Lisboa: Tagol, 1988. 
Campos Moreno. No anno de 160912. Nele, o Brasil aparece descrito de norte a sul (incluindo-se aí as capitanias de S. Vicente, Rio de Janeiro e Espírito Santo).

Ao contrário do anterior, cujo borrão (esboço) jamais foi passado a limpo, merecem atenção outros dois relatórios, contendo primorosas cartas iluminadas e aquareladas por João Teixeira Albernaz I (1602-1666): o Estado do Brasil Coligido das mais sertas notícias a pode aivntar, Dõ Jerônimo de Ataíde. Por João Teixeira Albernas, Cosmographo de Sva Magde. Anno: 163113, contendo 36 cartas; e o Descripção de Todo o marítimo da Terra de S. Crus chamado vulgarmente Brazil (c. 1640)14, com 32 cartas. Cinco cartas do atlas Estado do Brasil Coligido das mais sertas notícias... representam a costa do atual estado de São Paulo. Nelas é possível constatar que a Capitania de São Vicente estendia-se da barra do rio São Francisco do Sul até a ilha de Santo Amaro latual Guaruiál e a Capitania de Santo Amaro, da ilha de mesmo nome à baía de Ubatuba (Figuras 4-8). Trata-se de representações costeiras, ricas em topônimos e nelas observar-se a rede hidrográfica, a rede de vilas, fortalezas e engenhos de açúcar. Na linha das demais Relaciones Topográficas de Castilla y Geográficas de Índias (solicitadas para todo o império castelhano), essas cartas eram relatórios oficiais, inventariando todas as capitanias - da Coroa e de donatários -, com suas fortalezas, fortes, artilharia, tropas de ordenança, oficiais e homens de estado, declaração dos ordenados, soldos e despesas ordinárias, bem como receitas advindas do que nelas era produzido. As informações relatadas por escrito são espacializadas em cartas anexas, representando minuciosamente as particularidades geográficas e topográficas da faixa costeira, apontando seus inconvenientes do ponto de vista militar, acidentes geográficos da costa lportos notáveis; surgidouros de "bom fundo" para caravelas, navios, urcas e pataxos;

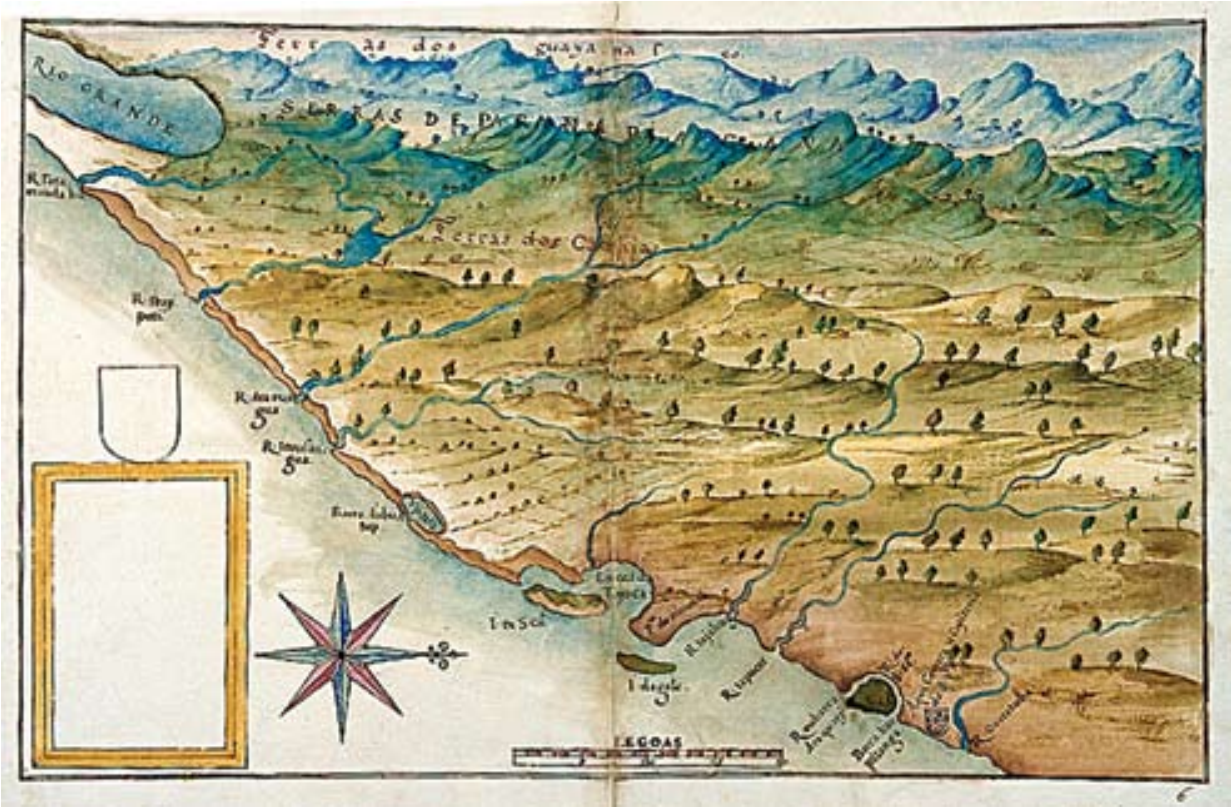

12. Os originais estão no Instituto dos Arquivos Nacionais, na Torre do Tombo em Lisboa. Curiosamente o autor deste relatório foi o sargentomor Diogo de Campos Moreno (e não o engenheiro-mor do Brasil Francisco de Frias da Mesquita). Braço direito do engenheiro-mor, Campos Moreno apresenta um curriculum invejável. Nasceu em 1566, em Tânger ou nos Açores, começando a servir como soldado em Flandres ao lado de Alexandre Farnese e passando, em 1602, ao Brasil, onde permaneceu até sua morte, em 1617. No Brasil, desempenhou importante ação como militar, exercendo funções de inspetor das fortalezas e artilharia, bem como se envolvendo diretamente em algumas campanhas, como a da reconquista do Maranhão aos franceses, em 1614, da qual deixou relato pormenorizado. Cf. M. Soromenho (1992, p. 202-203). Varnhagen, em 1854, atribui-lhe a autoria de outro relatório datado de 1612 - Rezão do Estado, do Brasil.. -, algo plausível, uma vez que já teria realizado o de 1609 . Sabe-se que entre 1612 e 1613 Campos Moreno esteve na Europa - quiçá levando consigo as notas originais desses relatórios para que fossem passados a limpo, aquarelados e iluminados -, regressando ao Brasil em 1614 .

13. Ver Isa Adonias (1960). O material descrito está na Mapoteca do Itamaraty.

14. Deste atlas, há sete cópias manuscritas, uma delas sediada na Pinacoteca de São Paulo / Coleção Brasiliana da Fundação Estudar.

Figura 4 - Sem título. In: Teixeira Albernaz I, João (1631)."Estado do Brasil Coligido das. mais: sertas notícias q pode aivntar, Dõ Jerônimo de Ataíde. Por João Teixeira Albernas, Cosmographo de Sva Magde. Anno: $1631^{\prime \prime}$. Carta 6ㄴ, $39 \times 61$ $\mathrm{cm}$. Mapoteca do Itamaraty - RJ. Fotografia de Vicente de Mello. 
Figura 5 - Capitania de São Vicente. In: Teixeira Albernaz I, João (1631)." Estado do Brasil Coligido das. mais: sertas notícias a pode aivntar, Dõ Jerônimo de Ataíde. Por João Teixeira Albernas, Cosmographo de Sva Magde. Anno: $1631^{\prime \prime}$. Carta 7, $39 \times 61 \mathrm{~cm}$. Mapoteca do Itamaraty - RJ. Fotografia de Vicente de Mello.

Figura 6 - Capitania de S. Victe. In: Teixeira Albernaz I, João (1631)."Estado do Brasil Coligido das. mais: sertas notícias a pode aivntar, Dõ Jerônimo de Ataíde. Por João Teixeira Albernas, Cosmographo de Sva Magde. Anno: 1631". Carta 8, $39 \times 61 \mathrm{~cm}$. Mapoteca do ltamaraty - RJ. Fotografia de Vicente de Mello.
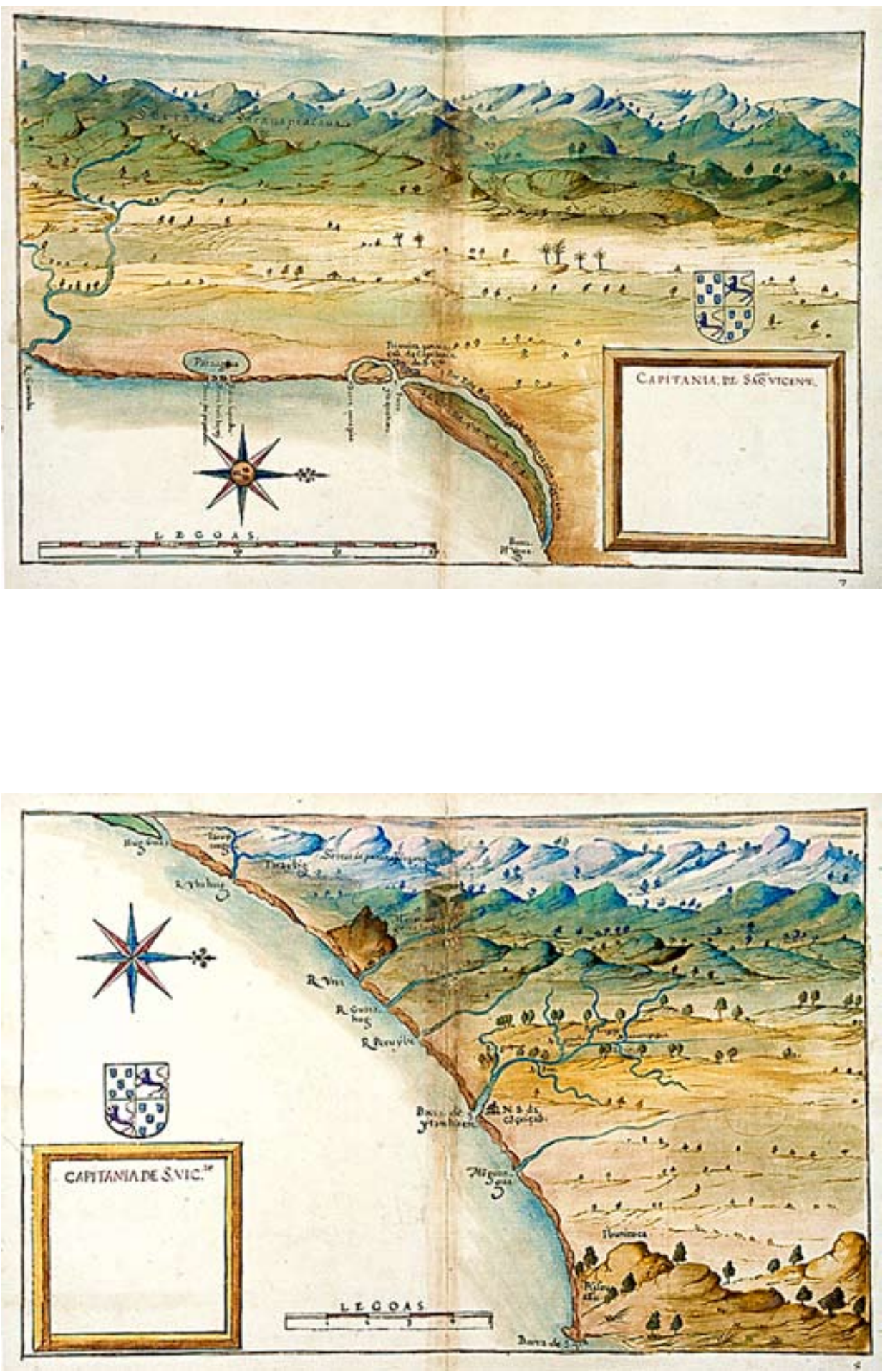

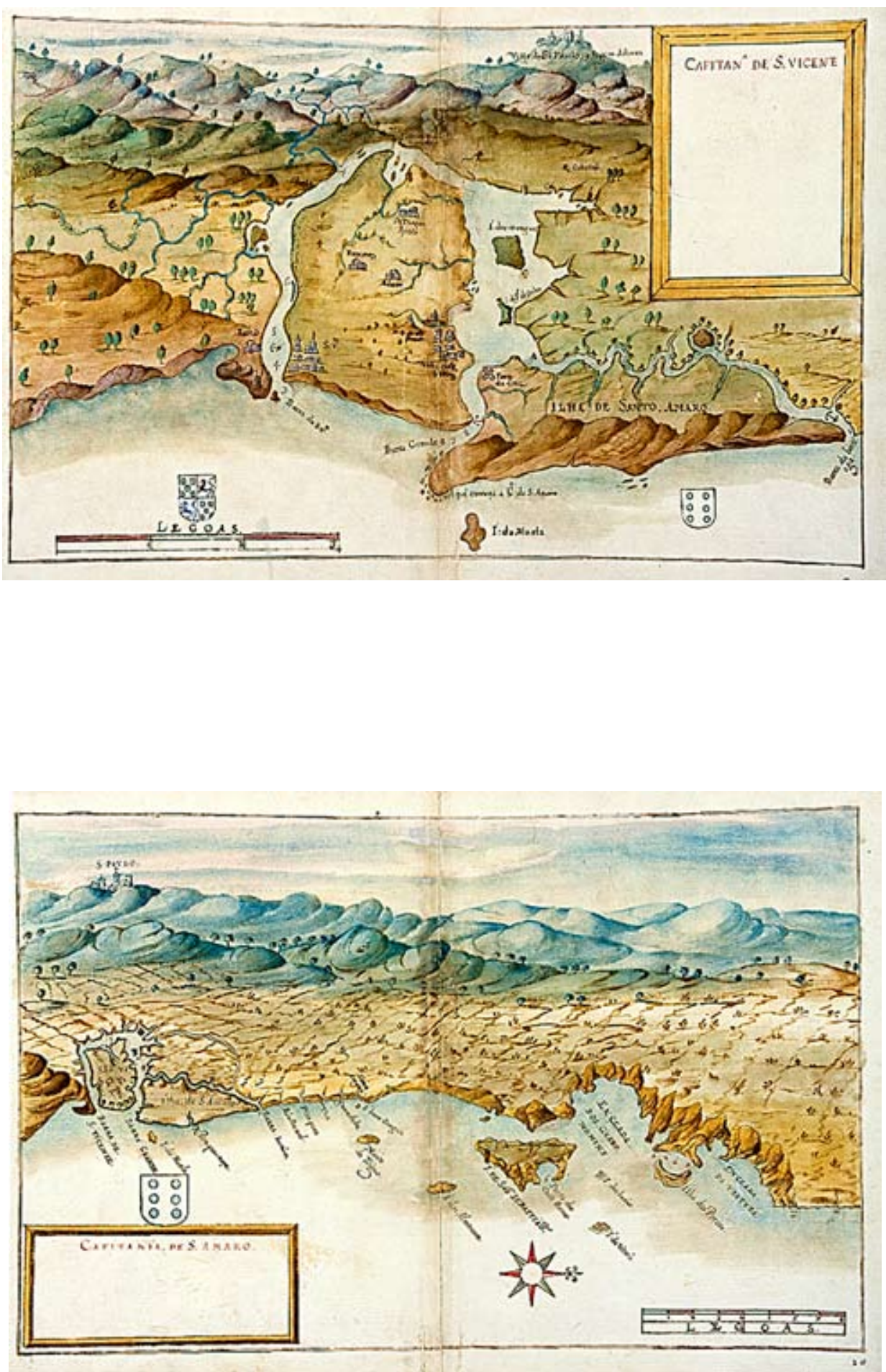

Figura 7. Capitan a de S. Vicente. In: Teixeira Albernaz I, João (1631)."Estado do Brasil Coligido das. mais: sertas notícias a pode aivntar, Dõ Jerônimo de Ataíde. Por João Teixeira Albernas, Cosmographo de Sva Magde. Anno: $1631 "$. Carta 9a $39 \times 61 \mathrm{~cm}$. Mapoteca do Itamaraty - RJ. Fotografia de Vicente de Mello.

Figura 8. Capitania de S. Amaro. In: Teixeira Albernaz I, João (1631)."Estado do Brasil Coligido das. mais: sertas notícias a pode aivntar, Dõ Jerônimo de Ataíde. Por João Teixeira Albernas, Cosmographo de Sva Magde. Anno: $1631^{\prime \prime}$. Carta 10으. $39 \times 61 \mathrm{~cm}$. Mapoteca do Itamaraty - RJ. Fotografia de Vicente de Mello. 
15. Descripção de Todo o marítimo da Terra de $S$. Crus chamado vulgarmente o Brazil (c.1640). Pinacoteca do Estado / Coleção Brasiliana da Fundação Estudar, 2003. Edição facsimilar.

16. Cf. N. G. Reis Filho (2004, p. 34).

17. Ver N. G. Reis Filho (2004, p. 230).

18. Idem, p. 230-232. ithas e ithetas com água e lenha; enseadas de grande pescaria; salinas; abrolhos, recifes perigosos, costa brava; correntes marítimas; barretas e calhetas), serras, rede hidrográfica costeira, terras despovoadas e sem proveito, zonas mais e menos férteis para plantação de mantimentos, os limites entre as capitanias hereditárias, vilas, cidades, fortalezas, fortes, redutos, aldeias, currais dos padres jesuítas, engenhos e fazendas. Para além da aura atual de obras de arte, refinadas por seus apelos estéticos, trata-se de "livros do Estado", contendo elementos estatísticos, militares e geográficos, normalmente realizados em mais de uma versão. A Descripção de Todo o marítimo da Terra de S. Crus chamado vulgarmente o Brazil relata as capitanias de São Vicente e Santo Amaro como uma zona fértil, ocupada por algumas fazendas e engenhos de açúcar, minas de ouro e um conjunto de 4 vilas - Cananeia (1600), Itanhaém (1561), S. Vicente (1532) e Santos (1545). No acesso às barras de Santos e de Bertioga, foram registrados três fortes, respectivamente, Forte da Crus - atual Forte de Vera Cruz de Itapema, no Guarujá - e os fortes de S. Felipe e de S. Tiago. O litoral norte paulista aparece absolutamente desguarnecido de povoações e fortalezas, o que nos leva a supor que os levantamentos da Descripção datem de período anterior à fundação das vilas de S. Sebastião (1636) e Ubatuba (1637)

Do Rio de S. Francisco / .../ vem continuando a Costa sempre ao Nornordeste ate a tha a q'chamaõ da Cananea / ... e nella há alguns surgidouros de bom fundo, como he hua Enceada a que chamaõ Parnagua /.../, e nove Legoas mais ao Nornordeste está outra barra de seis braças de fundo, e junto della temos a primeira povoação da Capitania de São Vicente. Mostrase a costa que vem do Rio e llha da Cananea ate o porto de S. Vicente e nella no Rio Una temos barra para Caravellas, e o mesmo no Rio Itanha. Em o porto de S. Vicente /.../ faz duas Barretas, a do Sul, he de S. Vicente tem 4 e 5 braças, e a do Norte que chamaõ dos Santos tem seis e sete; são ambos os surgidouros bonissimos, a terra fertilicima, e aves saudaveis, tem Engenhos de Asucar, e outras fazendas de proveito; produs Trigo e muitos fruitos, e mantimentos; e des legoas da barra para ocidente tem as Minas de S. Vicente de que se tira ouro, e seis legoas da barra dos Santos para o Norte está a barra de Bertioga que tem bom fundo, e por ella se entra em hum estreito que vay sahir no Rio dos Santos, e faz huã llha a q chamão de Santo Amaro que he do Conde de Monsanto, e tem esta llha boas fazendas, e Engenhos de Asucar"15

De mesma natureza são os preciosos desenhos descobertos por José Mindlin e por Nestor Goulart Reis Filho ${ }^{16}$ no Departamento de Cartografia y Bellas Artes de la Real Academia de História, em Madri. Não se sabe bem por que motivos, trata-se de "borrões" (croquis) que, como o relatório de Diogo de Campos Moreno de 1609, não mereceram versão aquarelada e iluminada. $\bigcirc$ primeiro mapa, intitulado Capitania de S. Visente ${ }^{17}$, representa a costa vicentina até a ilha de São Sebastião, rios e caminhos de acesso à vila de São Paulo (elevada a tal condição em 1560), contendo um desenho esquemático dela, possivelmente traçado entre 1599 e 1616. O segundo, sem tífulo, é uma versão aquarelada do anterior, talvez um pouco posterior. Nestor Goulart atribui ambos os desenhos ao engenheiro militar italiano Alessandre Massai ${ }^{18}$, dado que são parte de uma 
coleção referente ao sul de Portugal e ao Brasil, elaborada no século XVII, à qual está anexada uma Relação assinada por ele. Ainda no âmbito da política de recenseamento da costa brasileira por ocasião da União das Coroas Ibéricas (1580-1640), a coleção atestaria a presença, em solos paulistas, desse prestigioso engenheiro. Nestor Goulart acredita que Massai teria acompanhado o governador D. Francisco de Sousa que, por volta de 1599, assumira o governo da "repartição do sul", incluindo as capitanias de Espírito Santo, Rio de Janeiro e São Vicente, exatamente as que tiveram suas sedes representadas nos desenhos da coleção atribuída a Massai. Este poderia ter estado no Brasil entre 1599 e 1616, antes de regressar a Portugal e encabeçar o levantamento de mesma natureza do litoral alentejano e algarvio (1617), a Descripção do Reino do Algarve ${ }^{19}$, concluído em versão de luxo em 1621.

governador D. Francisco de Sousa permaneceu inicialmente em Santos e São Vicente, mas as Atas da Câmara de São Paulo atestam sua presença serra acima em 16 de maio de 159920. Acompanhado por um séquito qualificado de mineradores - Geraldo Betting e Jacques de Oalte -, dado que os motivos de sua nomeação como governador da então criada Repartição do Sul era organizar e motivar a população de São Paulo a percorrer o sertão em busca de ouro e pedras preciosas, trouxe também consigo dois importantes engenheiros italianos: Massai e Baccio da Filicaia. As notícias de mineração de ouro no Jaraguá reorientaram a política colonizadora nos tempos da União das Coroas Ibéricas, e D. Francisco foi deslocado às terras meridionais para estimular pesquisas e dar um caráter sistemático às incursões de entradas e bandeiras nos sertões. A Massai são atribuídas as Relaciones Geográficas da costa da Repartição do Sul; iá a Baccio da Filicaia, o primeiro esforço para estabelecer alguma disciplina no urbanismo da vila de São Paulo e orientar o seu crescimento. Segundo Nestor Goulart, teria sido Baccio da Filicaia ${ }^{21}$ o responsável pelo traçado das duas ruas retas fora dos muros do povoado: a rua Direita de São Bento e a rua Direita.

Em tempos do domínio felipino, também se atribui 22 o projeto inicial da Fortaleza de S. Amaro da Barra Grande a outro engenheiro militar italiano, Giovanni Battista Antonelli, que a teria projetado em 1583. Trata-se, quiçá, de um terceiro personagem ilustre que por aqui passou, deixando vestígios materiais.

Observa-se longa ausência de engenheiros militares na região vicentina entre o fim da União das Coroas lbéricas e a incorporação das capitanias de São Vicente e Santo Amaro pela Coroa, em decorrência das descobertas auríferas além serra da Mantiqueira. A documentação do Conselho Ultramarino existente no Arquivo Histórico Ultramarino, de Lisboa, atesta um único mapa, anônimo, datável desse ínterim - a [Planta da baía de Paranaguá/... / e a perspectiva da cidade de Paranaguá] (c. 1653) -, contemporâneo da época de criação da vila (1649) e decorrente do período da mineração de ouro na região, aliás, bastante significativa. As minas ao redor da Baía de Paranaguá estão perfeitamente documentadas no mapa ${ }^{23}$.

Os demais desenhos referem-se ao século XVIII, basicamente
19. Sobre Alexandre Massai, consultar: R. Moreira (1992, p. 97-107); e B. P. S. Bueno (2002; 2003, Capítulo 2).

20. Cf. N. G. Reis Filho (2004, p. 30).

21. Idem, p. 40

22. Ver V. H. Mori et al. (2003).

23. Ver N. G. Reis Filho (2000, p. 221). 
24. PLANTA da Villa de Santos..., anexa ao ofício datado de 13 de novembro de 1714 Lisboa: Arquivo Histórico Ultramarino (AHU), Inventário Castro e Almeida, Rio de Janeiro, n. 3385 e 3392 . Ver N. G. Reis Filho (2000, p. 197 e 165).

25. FORTALESA de Itapema..., anexa ao ofício datado de 4 de maio de 1714 . Lisboa: Arquivo Histórico Ultramarino (AHU), Inventário Castro e Almeida, Rio de Janeiro, n. 350 e 3385 . relacionando-se a quatro momentos da história da Capitania de São Paulo. A primeira série refere-se às primeiras décadas do século XVIII, tratando-se de projetos de fortificação para a Vila de Santos; a segunda foi realizada pelos padres matemáticos para o Novo Atlas da América Portuguesa (1729-1748); a terceira corresponde ao período da administração do Morgado de Mateus (1765-1775), pós-assinatura do Tratado de Madri (1750); e a quarta data do último quartel do século XVIII, sendo posterior ao Tratado de Santo Ildefonso (1777), com ênfase no período da administração do governador Bernardo José de Lorena.

Malgrado não ter sido cartografada entre o fim da União das Coroas Ibéricas (1640) e as duas primeiras décadas do século XVIII, a Capitania de São Paulo teve suas fronteiras bastante dilatadas em direção aos sertões do sul, a Minas Gerais, ao Mato Grosso e a Goiás, fruto da ação de vicentinos, taubateanos, ituanos e sorocabanos, só então alcunhados genericamente de "paulistas". Quer devido ao combate às missões jesuítas e aprisionamento de índios, quer devido à incessante febre de busca de ouro, os sertanistas paulistas contribuíram, e muito, no processo de expansão dos contornos das fronteiras da América portuguesa além da Linha de Tordesilhas.

A expansão material da Capitania, se mal documentada no período precedente encontra-se muito bem representada na cartografia a partir da terceira década do Setecentos.

Os projetos dos engenheiros João Massé e José da Silva Paes

A primeira série de desenhos do século XVIII data de c. 1714 a 1738. Não são mapas corográficos e geográficos, mas simples projetos arquitetônicos vinculados à melhoria do sistema de defesa da barra de Santos. Assinados por prestigiosos engenheiros militares, como os brigadeiros João Massé e José da Silva Paes, tais projetos são provavelmente eco da invasão francesa do Rio de Janeiro por Duguay Trouin, em 171 1, que condicionou o reforço militar dos principais portos relacionados direta ou indiretamente às Minas de Cataguases, recém-descobertas. Guarnecer o porto de Santos de um eficiente sistema de defesa significava proteger o principal acesso à cidade de São Paulo, elevada, em 171 1, à condição de cabeça da Capitania de São Paulo e Minas de Ouro, capitaneando lucrativas zonas no sertão além serra da Mantiqueira.

A Planta da Villa de Santos E de seu Porto, com suas Fortifficaçoens dessinadas de novo ${ }^{24}$, assinada pelo brigadeiro João Massé, relaciona-se a outra, de mesma natureza, referente ao Rio de Janeiro, ambas de 1714. São projetos jamais executados, objetivando a construção de muralhas ao redor do Rio de Janeiro e de Santos, com intuito de barrar a pirataria estrangeira. Soma-se, aos projetos citados, outro para a Fortalesa de Itapema, no Rio defronte da Villa de Santos $^{25}$, datado de c. 1714 e, provavelmente, também atribuível ao brigadeiro 
João Massé. $\bigcirc$ engenheiro ainda foi autor dos projetos de ampliação da Fortaleza de Santo Amaro da Barra Grande - hoje um dos mais belos patrimônios arquitetônicos do litoral paulista - a saber: a Planta da Fortaleza dessinada de novo na Barra Gr. de de Santos... (c. 1714) e a Planta de hua Fortaleza dessinada de novo na Villa de Santos... (c. 1714)26.

Massé era um importante engenheiro militar francês a serviço da Coroa portuguesa. Por Ordem Régia de 1712, foi promovido ao posto de brigadeiro de infantaria e incumbido de examinar e reparar as fortificações das capitanias do Rio de Janeiro, Bahia e Pernambuco ${ }^{27}$. Ao que tudo indica, os projetos de Massé para o Rio de Janeiro e para Santos não foram realizados, cabendo ao brigadeiro José da Silva $\mathrm{Paes}^{28}$ executá-los em parte. O Arquivo Histórico Ultramarino em Lisboa guarda dois projetos 29 para a Fortaleza de Itapema Fortaleza de Itapema (c. 1734) e [Planta da Fortaleza de Itapema] -, o último deles desenhado pelo brigadeiro José da Silva Paes (c. 1738).

José da Silva Paes ${ }^{30}$ foi igualmente dos melhores e mais experimentados engenheiros portugueses aqui atuantes. Destacou-se na defesa da itha de Santa Catarina e na construção de fortificações. Foi governador de Santa Catarina e verdadeiro fundador do Rio Grande de São Pedro. Serviu no Brasil, na primeira metade do século XVIII, como brigadeiro dos Exércitos de Sua Magestade e governador de capitanias do sul. Teve destacada atuação militar nas lutas provocadas pela demarcação dos limites entre as Coroas portuguesa e espanhola. Além de engenheiro militar, foi um excelente arquiteto civil - autor dos projetos da Matriz e do Palácio dos Governadores da vila de N. S. do Desterro latual Florianópolis ${ }^{31}$.

Os mapas dos padres matemáticos (1729-1748)

Levantamentos oficiais do sertão só ocorreram a partir de 1729, por ocasião da vinda dos "padres matemáticos" ao Brasil. A missão dos jesuítas astrônomos Domingos Capacci e Diogo Soares liga-se ao problema da Linha de Tordesilhas ${ }^{32}$, cuja demarcação convencionada em 1494 estava sendo questionada pela rápida evolução do povoamento de portugueses nos sertões da Amazônia, Mato Grosso e Goiás, terras então pertencentes aos espanhóis. Por Ordem Régia, de D. João $V$, a missão principal dos padres matemáticos era a elaboração de uma "Nova Carta do Brasil", com latitudes e longitudes observadas, delineando uma outra estratégia de domínio territorial ${ }^{33}$. Em 1729, Capacci e Soares partiram de Lisboa rumo ao Rio de Janeiro, com a missão de cartografar a vasta região mineira e a costa atlântica, desde Cabo Frio à Colônia do Sacramento.

Este primeiro registro oficial dos sertões ancorava, portanto, o ambicioso projeto de apropriação de um espaço eminentemente valioso, sendo atribuição dos jesuítas matemáticos figurar cartograficamente um espaço que se pretendia
26. Ambos em Lisboa, no Arquivo Histórico Ultramarino.

27. Ver F. de S. Viterbo (1988).

28. Ver H. Mori (2003, p. 83).

29. Ver projetos em J. J. de A. Arruda $(2000$, p. 18 ; 22 23).

30. Ver F. de S. Viterbo (1988).

31. Cf. B. P. S. Bueno (2003, p. 392-393).

32. Sobre os problemas de soberania então existentes e a questão da longitude na precisão dos mapas setecentistas, ver B. P. S. Bueno (2004).

33. Ver A. F. de. Almeida (1999; 2001). 
34. Ver J. Cortesão (1984).

35. Ver B. L. Toledo (1972, p. $27-28,32$ ).

36. Diogo Soares e Domingos Capacci, Carta 9a. da costa do Brazil desde a Barra de Santos até à da Marambaya (c. 1737). Lisboa: Arquivo Histórico Ultramarino, Cartografia Manuscrita do Brasil, n. 1142 .

37. Ver Heloísa Liberalli Bellotto (1979). negociar e controlar. Segundo Jaime Cortesão ${ }^{34}$, a missão dos padres matemáticos foi a primeira expedição geográfica e cartográfica enviada por uma nação europeia a qualquer das Américas, com fins sistemáticos de Estado, como estudo preparatório para delimitar a soberania política entre os domínios de nações confinantes.

Assim, enquanto, no sul, portugueses e espanhóis alternavam períodos de relativa tranquilidade com outros de francas hostilidades, que só iriam cessar com o Armistício de 1737, os geógrafos do rei procediam a um minucioso trabalho destinado a oferecer preciosa fundamentação às negociações que se desenrolariam entre esse armistício e o Tratado de Madri, assinado em $1750^{35}$.

Dos 31 mapas e plantas então elaborados, destacam-se a Nova e 1 a. carta da Terra Firme, e costas do Brasil ao Meridiano do Rio de Janeiro, desde o Rio da Prata athe Cabo Frio, com o novo caminho do Certão do Rio Grande athe a cidade de S. Paulo, assinada por Diogo Soares, e a Carta 9a. da costa do Brazil desde a Barra de Santos até à da Marambaya (c. 1737), assinada por Diogo Soares e Domingos Capacci ${ }^{36}$. Esta última representa, pela primeira vez, a rede urbana, fluvial e viária do planalto paulista e suas articulações com o litoral. Com ícones cartográficos específicos, na Carta 9a. dos padres matemáticos constavam, no planalto, a Cidade de São Paulo e as vilas de Santana de Mogi das Três Cruzes, Jacarey, Taubaté e Pindamonhangaba, em meio a diversas capelas e freguesias, dentre as quais a de S. José. Observa-se a trilha que conectava a Cidade de São Paulo às vilas litorâneas de Santos e São Vicente, bem como o caminho que articulava Taubaté e Guaratinguetá à Freguesia do Facão (atual Cunha) e ao porto de Guarauna (atual Parati). As vilas de São Sebastião e "Embatuba" (Ubatuba) aparecem relacionadas ao planalto por vias fluviais, claramente bloqueadas pelos contrafortes da Serra do Mar, onde residiam suas nascentes. Nota-se ainda entre as Serras do Mar e da Mantiqueira as bacias, não comunicantes, dos rios Tietê e Paraíba do Sul (Figura 9).

A cartografia do período da administração do Morgado de Mateus (1765-1775)

O desmembramento da Capitania de São Paulo - das capitanias das Minas Gerais, de Goiás, e de Mato Grosso - condicionou a sua desativação e conversão em simples comarca do Rio de Janeiro. Entre a desativação, em 1748, e a "restauração da Capitania de São Paulo"37, em 1765, raros foram os levantamentos cartográficos ali realizados.

Os conflitos com os espanhóis, no Sul, condicionaram a "restauração" em 1765 e, nessa ocasião, foi enviado D. Luís Antônio Botelho de Souza Mourão, - Morgado de Mateus, como novo governador. Nas correspondências expedidas ao Conselho Ultramarino ao longo dos dez anos de sua administração, o Morgado 
de Mateus reclamou frequentemente da carência de engenheiros para dar suporte às suas ações, o que o obrigou a projetar fortalezas e desenhar mapas.

No período, foram registrados vastos sertões que se ansiava converter em território da Coroa (lvaí, Tibagi, Campos de Guarapuava), destacando-se a presença de um maior número de engenheiros na Capitania de São Paulo, especialmente Teotônio José Juzarte ${ }^{38}$ e José Custódio de Sá e Faria.

Juzarte dispensa comentários, iá que é o objeto de estudo do artigo de Glória Kok no presente dossiê39. Já José Custódio de Sá e Faria (1710-1792)40 foi sem dúvida o mais importante engenheiro militar aqui atuante ${ }^{41}$, legando-nos um corpus cartográfico excepcional. Sua biografia ilustra a multifacetada ação desses profissionais e aventuras a que estiveram submetidos no processo de devassamento e representação das terras descobertas no Novo Mundo. Indiretamente, a serialização das suas cartas geográficas, corográficas e topográficas permite acompanhar a dilatação dos tentáculos metropolitanos em solos coloniais e o processo de produção técnica dos mapas - do borrão às aguadas -, descortinando nas entrelinhas os desígnios políticos que orientavam
38. Ver J. S. de Souza e M. Makino (2000); e Glória Kok (2004).

39. Ver G. Kok. Vestígios indígenas na cartografia do sertão da América portugue sa.

40. Ver B. P. S. Bueno (2006).

41. Ver B. L. de Toledo (1972, p. 38-57).

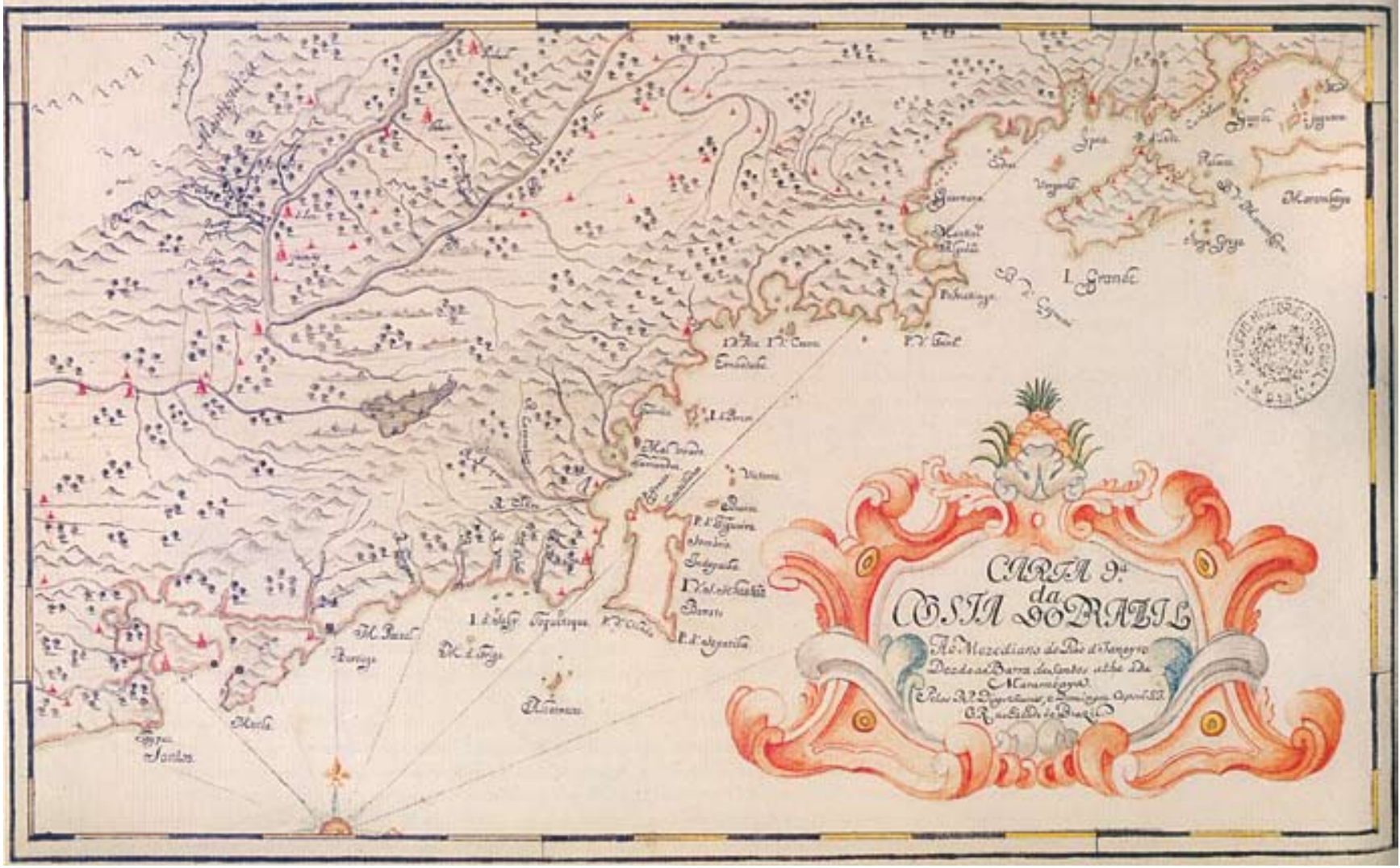

Figura 9 - Carta 9a. da Costa do Brazil Ao Meridiano do Rio de Janeiro Desde a Barra de Santos athe a da Marambaya". Autores: Diogo Soares e Domingos Capacci. Data: [c. 1737]. Dimensão: 18,8 × 31,7 cm. Cartografia Manuscrita do Brasil - n. 1142 Arquivo Histórico Ultramarino - Lisboa. 
42. Ver especialmente os capítulos 2, 3 e 5 em B. P. S. Bueno (2003).

43. O Real Decreto que o nomeia capitão-engenheiro datado de 1749 , apresenta uma resumida biografia. Apud F. S. VITERBO (1988, v. III, p. 1).

44. Cf. F. de S. VITERBO (1988, v. III, p. 1).

45. Ver B. L. de Toledo (1972, p. 38-57). a sua feitura e a ardilosa trama de relações que os articulava. Nesse sentido, cabe aqui uma breve digressão.

José Custódio de Sá e Faria é representante exemplar de uma geração formada sob o impulso renovador do ensino de cartografia nas academias militares, encabeçado por Manoel de Azevedo Fortes ${ }^{42}$. Apresentava sólida formação teórica como ex-partidista da Academia Militar das Fortificações, de Lisboa, onde se aplicou à "profição de Engenheiro com todo cuidado e estudo"43, tendo feito progressos que constam "das Certidões juntas do Engenheiro-mor do reino, e do Lente Substituto da ditta Academia, por onde se vé le do seu Provimento que tambem ajunta) ter sido examinado varias vezes dentro do Tribunal das Juntas dos Trez Estados, e sempre ficar aprovado pelos Examinadores, e Ministro do Tribunal"44. Em 1749, aos 39 anos, foi promovido a capitão de infantaria com exercício de engenheiro e, dois anos mais tarde, enviado ao Brasil com posto de sargento-mor de infantaria, integrando a Primeira Expedição Científico-Demarcatória (1753), chefiada por Miguel Angelo Blasco. Atuou na Comissão do Sul sendo, entre 1764 e 1771, incumbido de governar a recém-readquirida Colônia do Sacramento. Na Comissão do Sul, da expedição científico-demarcatória enviada ao Brasil por ocasião do Tratado de Madri (1750), de todos os integrantes, Sá e Faria foi o que mais se distinguiu, tanto como engenheiro militar quanto como cartógrafo, arquiteto, administrador e homem de armas. Com rápida ascensão na hierarquia militar, em 1760 foi promovido a tenente-coronel e, em 1761, a coronel. Com a anulação do Tratado de Madri, em 1761, e o início das hostilidades entre portugueses e espanhóis na América Meridional em outubro de 1762, o General Ceballos sitiou e rendeu a Colônia do Sacramento, além de importantes fortificações do Rio Grande de São Pedro (fortes de Santa Thereza, São Miguel e Rio Grande de São Pedro), ocupando a região em maio de 1763. O Tratado de Paz, firmado em agosto deste ano, pôs temporariamente fim às hostilidades e, em dezembro, a Colônia do Sacramento foi entregue aos portugueses. Nessa ocasião, Sá e Faria foi promovido a governador dos "continentes do Rio Grande de São Pedro"45. A missão de governar uma região em pé de guerra lhe conferiu o posto de brigadeiro, em outubro de 1771.

José Custódio de Sá e Faria conhecia bem a região a oeste da Capitania de São Paulo, pois lá estivera 20 anos antes, como Comissário da Terceira Partida de Demarcação. Por isso, em outubro de 1771, o Secretário de Estado Martinho de Mello e Castro enviou-the carta, incumbindo-o de dirigir-se a São Paulo e ao pequeno forte chamado de N. S. dos Prazeres do Rio Iguatemi. Com certo atraso, o brigadeiro Sá e Faria cumpriv a missão, chegando em São Paulo apenas em julho de 1772 e partindo para o lguatemi apenas em outubro de 1774. Após retornar da viagem, foi incumbido de nova inspeção no litoral Sul da Capitania, que também resultou em apontamentos, hoje guardados na Mapoteca do Itamaraty. Em 1776, foi convocado a deixar a Capitania de São Paulo e governar o Rio Grande de São Pedro, novamente em conflito com os 
castelhanos. Em fevereiro de 1777, Ceballos cercou a ilha de Santa Catarina e dela se apoderou. Sá e Faria foi designado para negociar a capitulação, sendo aprisionado como refém. Transferido para Buenos Aires, em abril de 1777, permaneceu a serviço dos espanhóis até morrer, em 1792. Lá, entre outras atividades, realizou o "Plano de Buenos Aires" (1780), com todas as suas ruas, desníveis e obras a realizar, bem como as fachadas para importantes igrejas, como as catedrais de Montevidéu e Buenos Aires, as igrejas de Guadalupe e de Maldonado, no Uruguai, e parte do Convento de S. Francisco, em Buenos Aires. Personagem estratégico, com profundo conhecimento da região brasileira em conflito com os castelhanos, e reconhecida capacidade como arquiteto e "urbanista", de priosioneiro de guerra Sá e Faria tornou-se um dos principais engenheiros a serviço dos espanhóis na Argentina e no Uruguai. Traidor, agente duplo, o fato é que os espanhóis não o deixaram escapar. Não por acaso, os borrões da viagem de São Paulo à Fortaleza do Iguatemi, hoje pertencentes à Mapoteca do Itamaraty no Rio de Janeiro, foram comprados em Buenos Aires, no século XIX, pelo diplomata Duarte da Ponte Ribeiro. Seu legado inclui também inúmeras cartas topográficas, corográficas e geográficas, bem como primorosos desenhos de vilas e fortalezas da América meridional portuguesa, relatórios das expedições realizadas, hoje pertencentes a acervos diversos, tais como à seção de obras raras da Biblioteca Municipal Mário de Andrade, em São Paulo, a Biblioteca Nacional do Rio de Janeiro, a Mapoteca do Itamaraty, o Arquivo Histórico do Exército, todos no Rio de Janeiro, entre outros.

Da expedição ao Iguatemi, restaram os borrões (rascunhos de campo), primeiros esboços de gabinete, segundas e terceiras reduções, o diário e os mapas definitivos. Através dessa série, rara e inédita, hoje pertencente à Mapoteca do Itamaraty, é possível reconstituir o processo da arte de fazer mapas. De borrões mais naturalistas a versões definitivas mais abstratas - reduzidas em escalas gráficas diversas e codificadas segundo padrões de representação internacionais -, a série revela os mecanismos de tradução das vivências de campo em linguagem cartográfica de gabinete.

Os desígnios que orientaram a expedição de Sá e Faria à Fortaleza do Iguatemi $^{46}$ seguiam expressas ordens régias. $\bigcirc$ rei e o marquês de Pombal, seu primeiro-ministro, reprovavam o projeto de defesa do Viamão - encabeçado pelo então governador da Capitania de São Paulo, o Morgado de Mateus - por meio de uma "poderosa diversão feita aos castelhanos pelo sertão de lgatemy" 47. As ordens régias alertavam quanto à prioridade da porção meridional do Brasil em relação ao oeste da Capitania de São Paulo, posicionando-se contrariamente à política territorial empreendida por D. Luís Botelho de Souza Mourão: "Em primeiro lugar, que Sua Magestade estima muito mais a perda de uma só legua de terreno na parte meridional da America portugueza, que cincoenta leguas de sertão descobertas no interior dessa capitania". [...] "A parte meridional da América portugueza uma vez perdida nunca mais se poderá recuperar"48.

A leitura do diário nos permite constatar as dificuldades inerentes a viagens tão longas. De São Paulo, junto do brigadeiro Sá e Faria, partiram o
46. "Ordens que El-Rei Nosso Senhor foi servido mandar à Capitania de S. Paulo em 22 de abril d'este presente anno de 1774 para que o disposto n'ellas se execute litteralmente, sem modificação, interpretação ou alteração que ella seja”. Apud José Custódio de Sá e Faria (1876).

47. Idem, ibidem.

48. Idem, ibidem. 
49. Ver G. Kok (2004, p. 198202). Ver [Diário e mapas das viagens de José Custódio de Sá e Faria... 1774]. Mapoteca do Itamaraty - Rio de Janeiro.

50. Trata-se da edição original do Diário da Viagem..., de José Custódio de Sá e Faria, datado de 1775 , que está na Coleção Duarte da Ponte Ribeiro do Arquivo Histórico do Itamaraty no Rio de Janeiro. tenente de artilharia Jeronymo da Costa, o tenente de infantaria Joaquim José Botelho, o alferes de infantaria Manoel Rodrigues Lobão, o sargento de artilharia José Pinto da Silva, e 22 soldados de artilharia do Rio de Janeiro. Da Freguesia de Araritaguaba (atual Porto Feliz), partiram dez canoas "com mantimentos e trem" e mais 56 pilotos e remadores (índios e bastardos) e 19 "presos em ferro". É notória a advertência, nas Ordens Régias, à necessidade de bons práticos, "sertanistas paulistas", afeitos ao sertão. A viagem demorava cerca de dois meses, sendo ideal a monção de outono-inverno, correspondente ao período de seca (abril/maio-junho/agosto). O percurso envolvia trecho por terra - da cidade São Paulo a ltu - e, por via fluvial, a partir da Freguesia de Araritaguaba, pelos rios Tietê, Paraná e lguatemi. A expedição partiu de São Paulo, em 3 de outubro de 1774, e chegou à Freguesia de Araritaguaba no dia 6 do mesmo mês. $\bigcirc$ caminho terrestre era bom e margeava o Tietê. Do Porto de Araritaguaba partiu-se alguns dias mais tarde (12.10.1774), chegando à Praça de N. S. dos Prazeres do Iguatemi, em 30 de novembro de 1774. Cerca de um mês levava a descida do Rio Tietê ao Rio Paraná (12.10-8. 1 1); cerca de dez dias a descida do Rio Paraná ao Rio Iguatemi (8.1 1-19.11) e, cerca de dez dias, a subida do Rio Iguatemi até a Fortaleza de N. S. dos Prazeres (19.1 1-30.11) (Figura 10). O meio de transporte eram simples canoas, como a esboçada nos borrões (Figura 11 1). Em geral, a viagem começava logo cedo, às 6 horas da manhã e estendia-se até às 5 da tarde, com parada para "jantar", pasmem, às 11 horas da manhã. Nos borrões encontra-se registrado todo o percurso: profundidade e largura dos rios, afluentes, ilhas, cachoeiras, itaipavas, sítios, fazendas, vilas e pousos. Cachoeiras trabalhosas obrigavam contínuas "varações" - trechos por terra, com as canoas nas costas. Da Freguesia de Araritaguaba até a sua barra, o rio Tietê tinha 36 cachoeiras e dois saltos. Em outubro e novembro, período da viagem, as chuvas e tempestades eram frequentes, durando até dois dias sem parar. Nesse período, as epidemias ("varíola e febres malignas") eram a grande ameaça, além dos mosquitos, bernes, carrapatinhos, moscas, cobras, formigas e marimbondos. Para o pouso, levavam-se barracas e redes. Os mantimentos eram pouco variados - farinha, feiião, toucinho, aguardente, azeite e sal. Antas e peixes (dourados, jaús - "de feitio de bagres, alguns de 7 palmos de comprido, de máo sabor e sêcco; assemelha-se ao bacalháo" - e pacus de gosto bom) completavam o cardápio ${ }^{49}$.

Em campo, com bússola e relógio em punho, os contornos dos rios delineavam-se em simples "borrões" riscados a lápis num caderno de notas ("o borrador ou caderno de lembrança") (Figuras 12-16). No gabinete, os rascunhos eram passados a limpo. Uma trama ortogonal balizava as primeiras (Figuras 17-18), as segundas (Figura 19) e as terceiras reduções dos desenhos, em diferentes escalas gráficas (Figura 20).

Datado de 31 de janeiro de 1775, exatos dois meses entre a chegada no Iguatemi e o regresso a São Paulo, o Diário50, passado a limpo, logo foi encaminhado ao ministro e secretário de Estado dos Negócios da Marinha e 


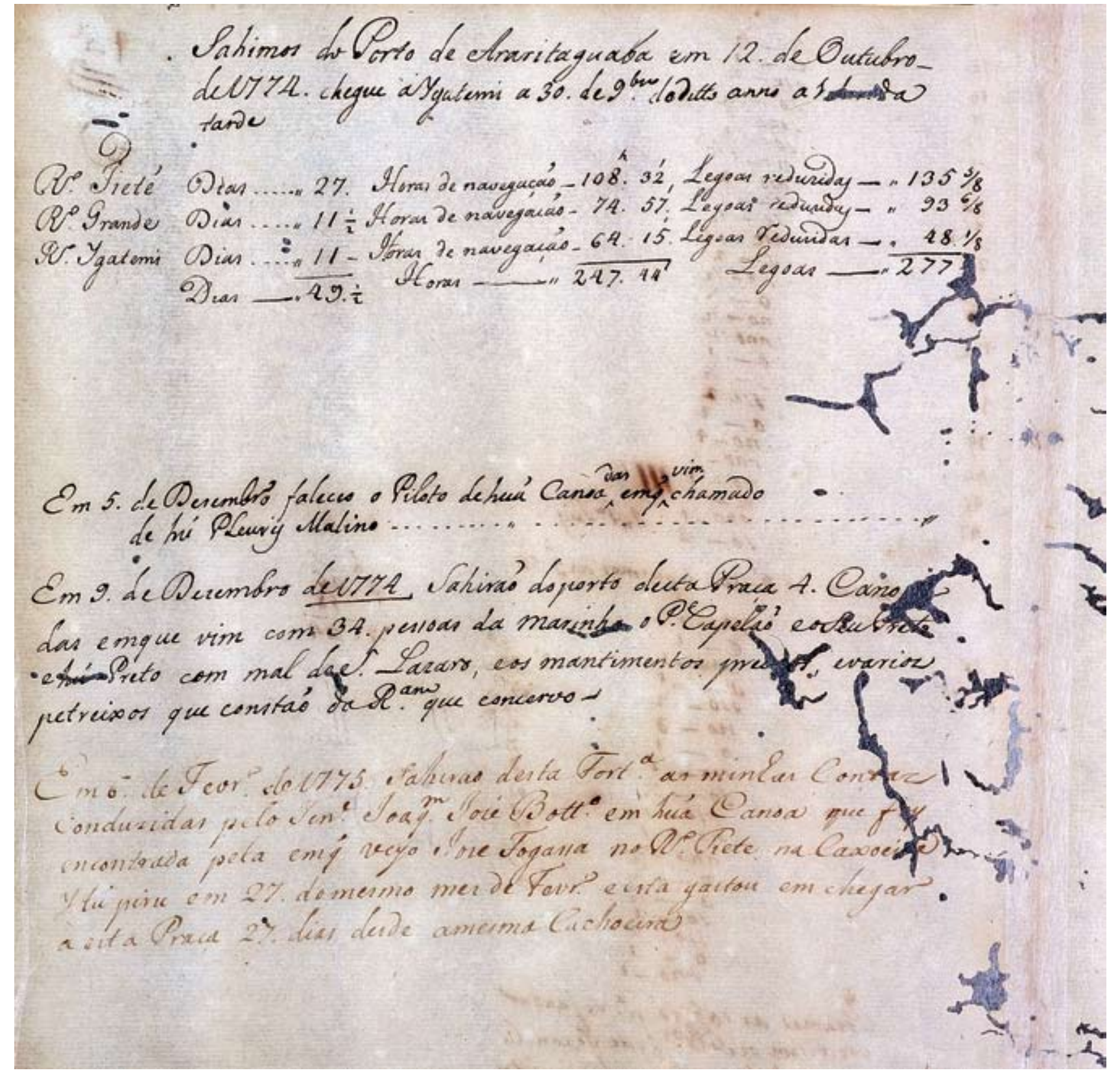

Figura 10 - [Diário e mapas das viagens de José Custódio de Sá e Faria, da Cidade de São Paulo até o Presídio de $N \cong S \cong$ dos Prazeres, no rio lguatemi, e da mesma Cidade de até a Vila de Paranaguá, nos anos de 1774 a 1776]. Formato original: $29 \mathrm{X}$ 19,5 cm. Mapoteca do Itamaraty - Rio de Janeiro. Fotografia de Vicente de Mello. 


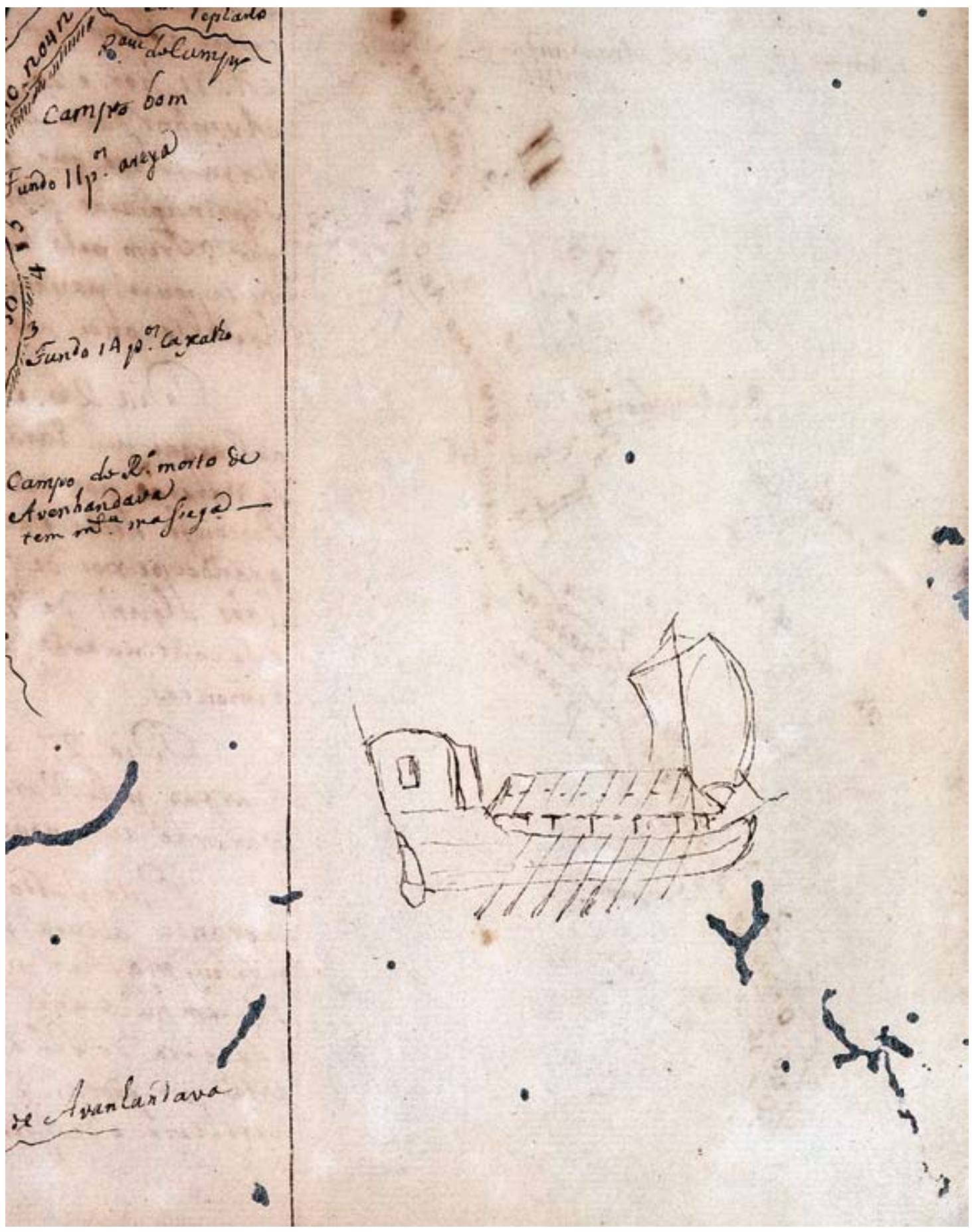

Figura 11 - Embarcação utilizada na viagem de José Custódio de Sá e Faria de São Paulo à Fortaleza do Iguatemi. In: [Diário e mapas das viagens de José Custódio de Sá e Faria, da Cidade de São Paulo até o Presídio de $N \stackrel{\sim}{ } \stackrel{9}{\varrho}$ dos Prazeres, no rio lguatemi, e da mesma Cidade de até a Vila de Paranaguá, nos anos de 1774 a 1776]. Formato original: 29 X 19,5 cm. Mapoteca do Itamaraty - Rio de Janeiro. Fotografia de Vicente de Mello. 


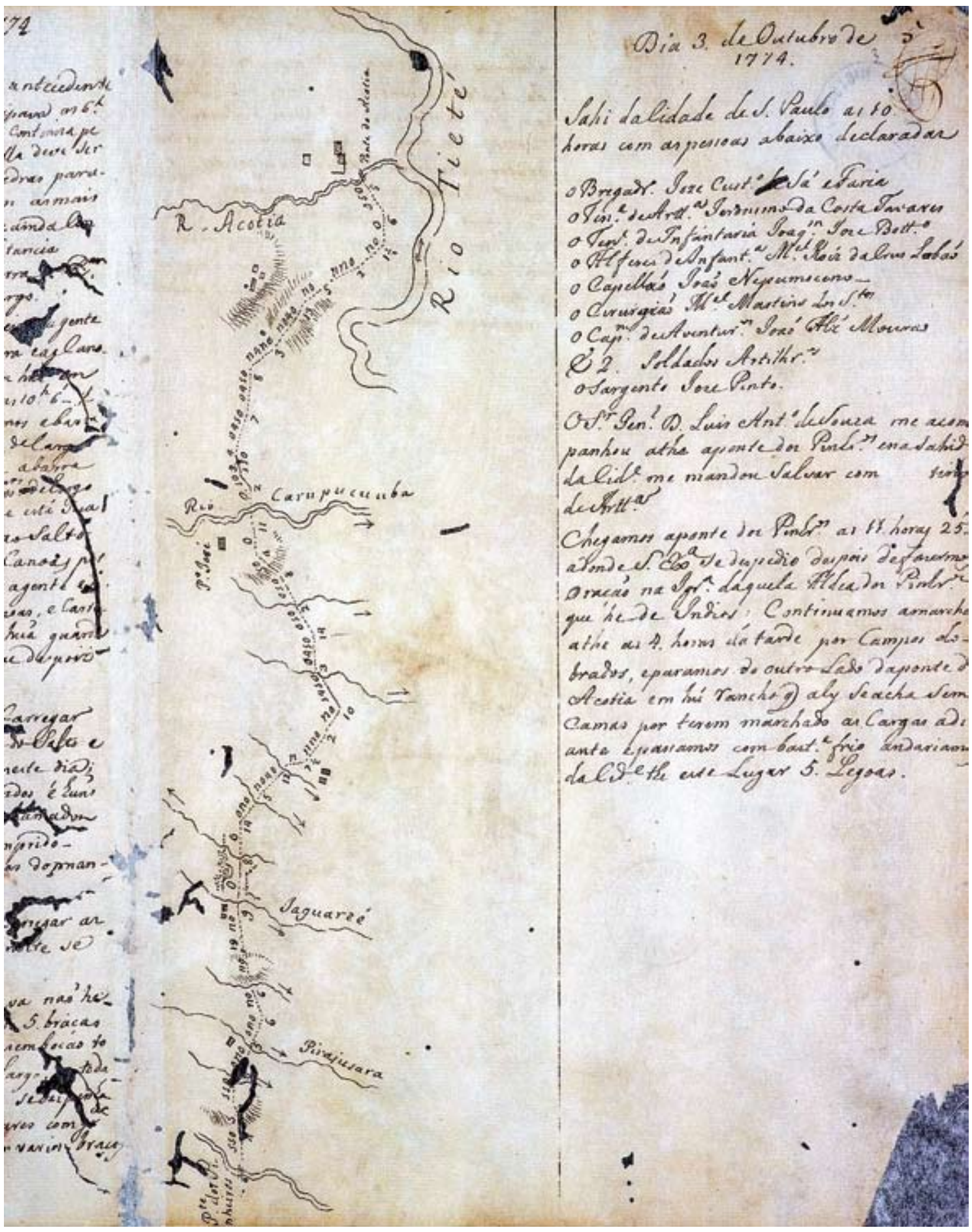

Figuras 12 a 16 - Os "borrões" realizados em campo. In: [Diário e mapas das viagens de José Custódio de Sá e Faria, da Cidade de São Paulo até o Presídio de $N \stackrel{9}{ } S^{a}$ dos Prazeres, no rio Iguatemi, e da mesma Cidade de até a Vila de Paranaguá, nos anos de 1774 a 1776]. Formato original: 29 X 19,5 cm. Mapoteca do ltamaraty - Rio de Janeiro. 


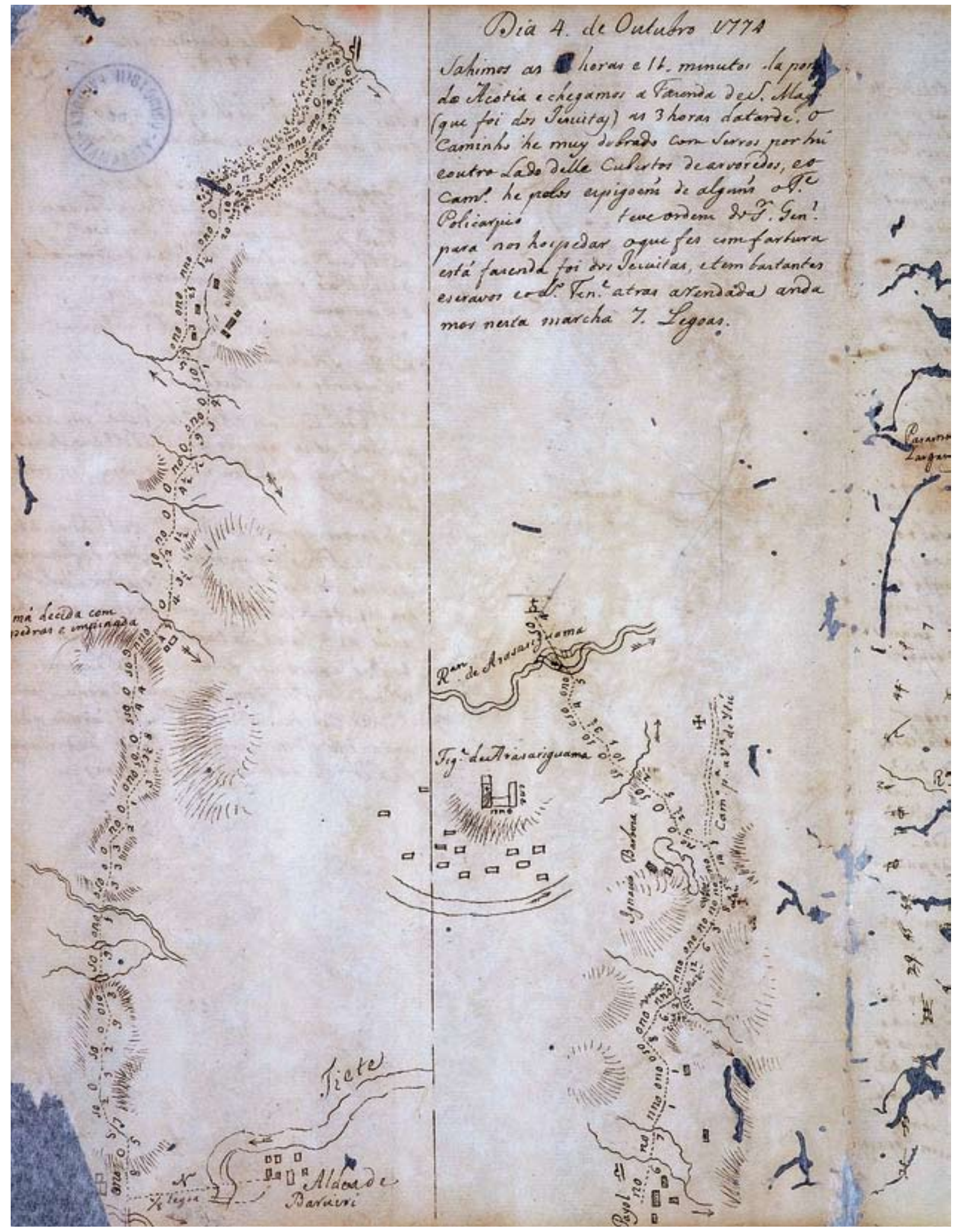




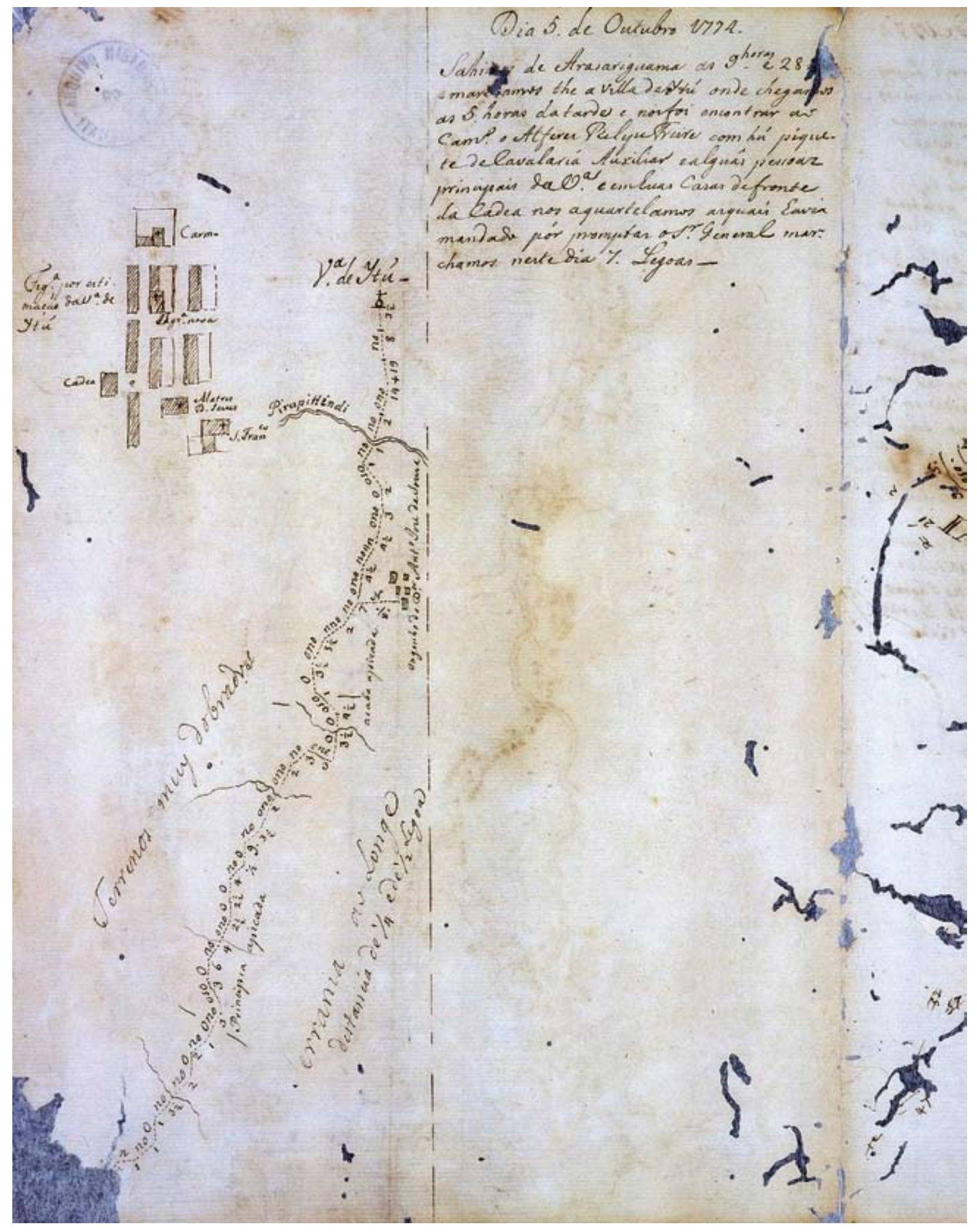




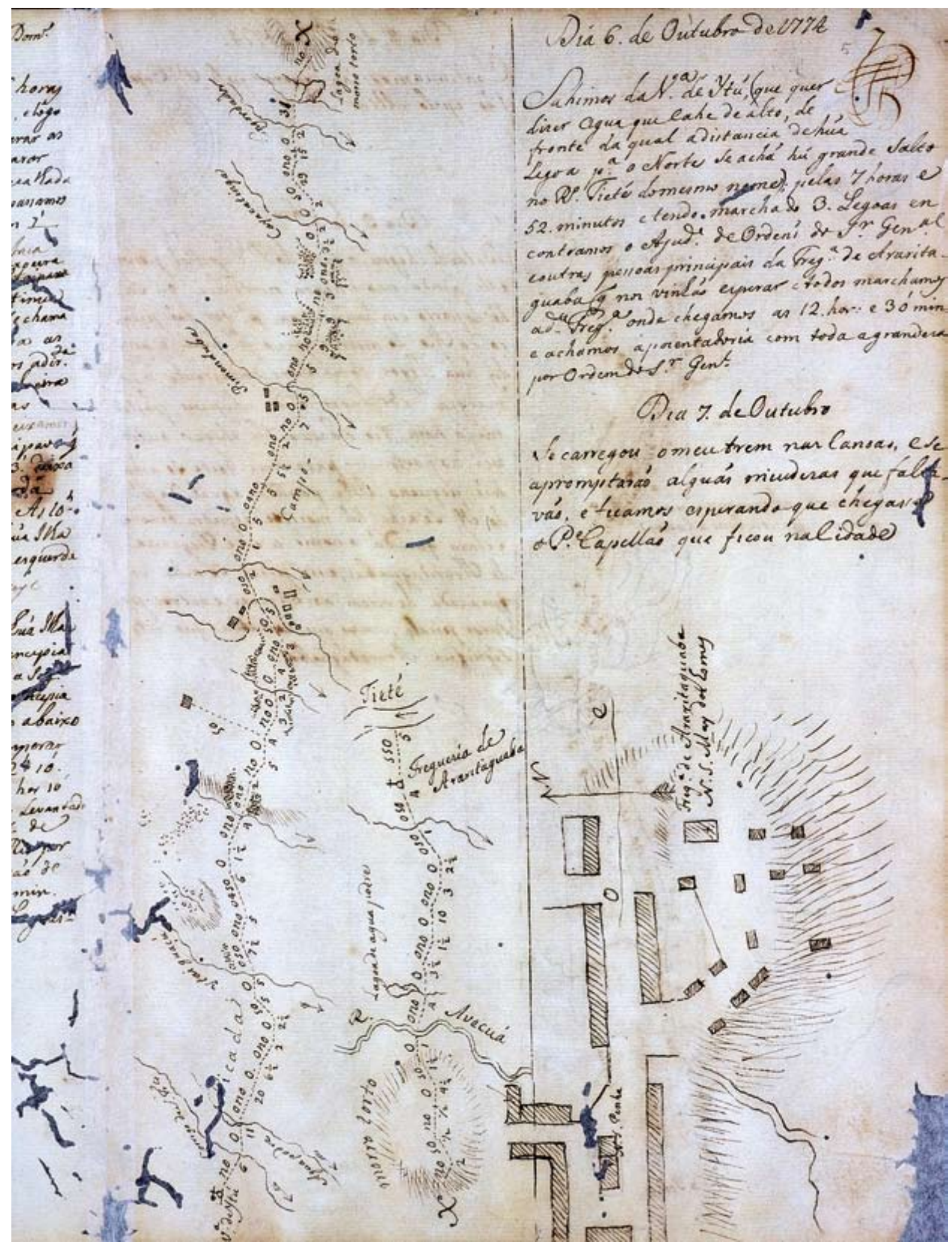




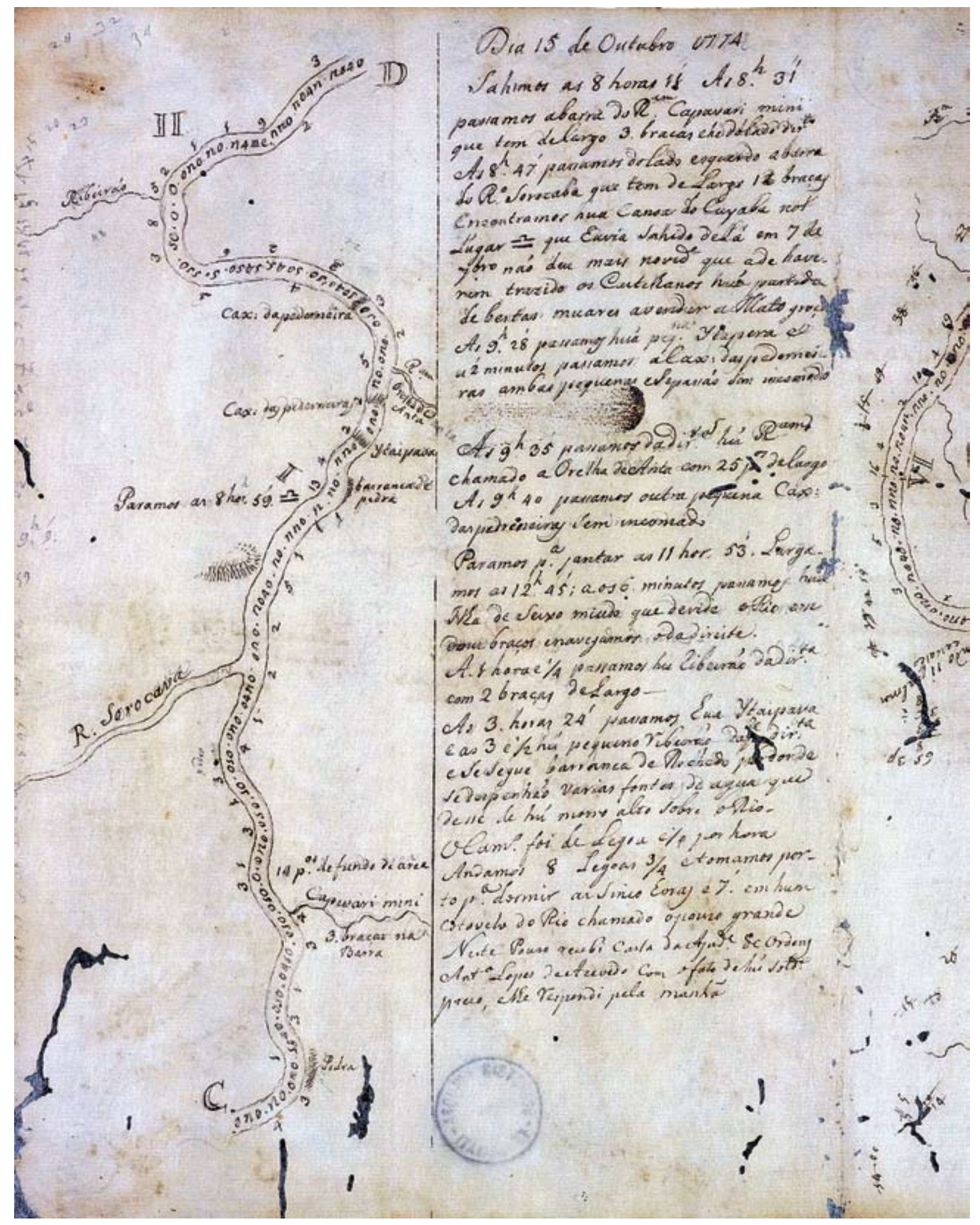


Figuras 17 e 18 - As primeiras "reduções" de gabinete. In: "34 Planos do Rio do Tietê desde o porto de Araritaguaba, e Paraná até o Iguatemi, em esboço". Autor: José Custódio de Sá e Faria. Dimensão: 35,0 × 21,5cm. Mapoteca do Itamaraty - Rio de Janeiro. Fotografias de Vicente de Mello.

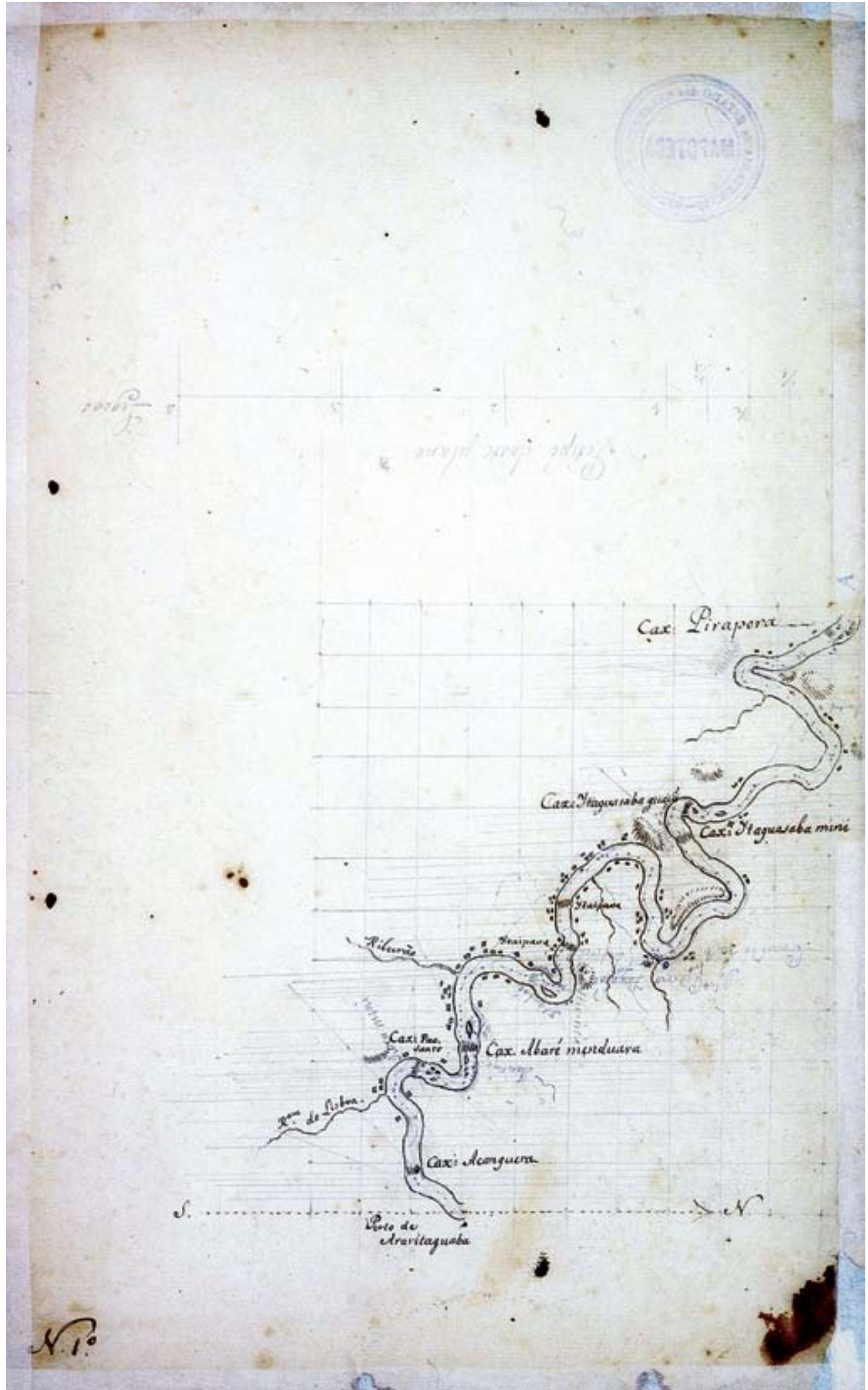

Anais do Museu Paulista.v. 17.n.2. jul.-dez. 2009. 


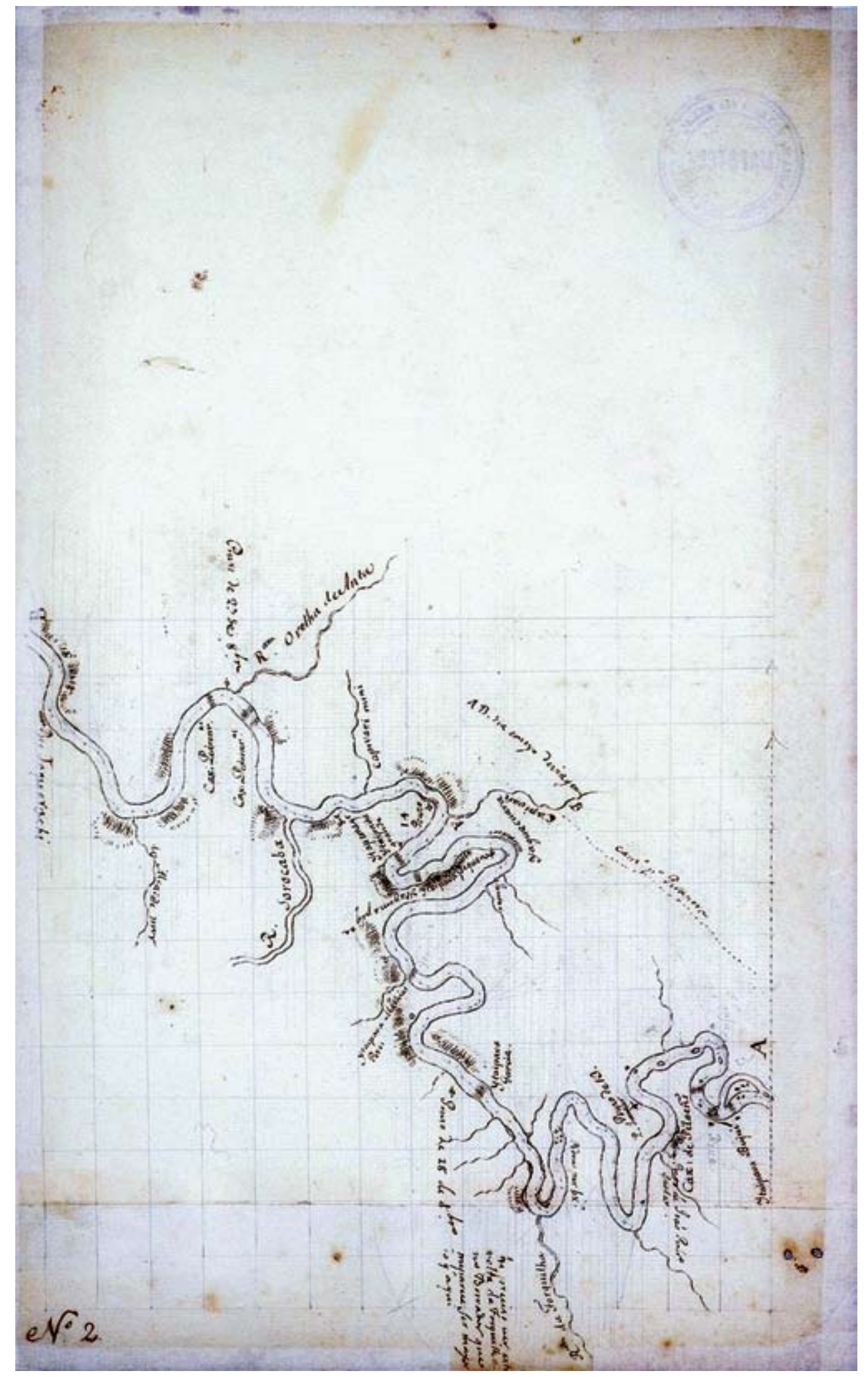




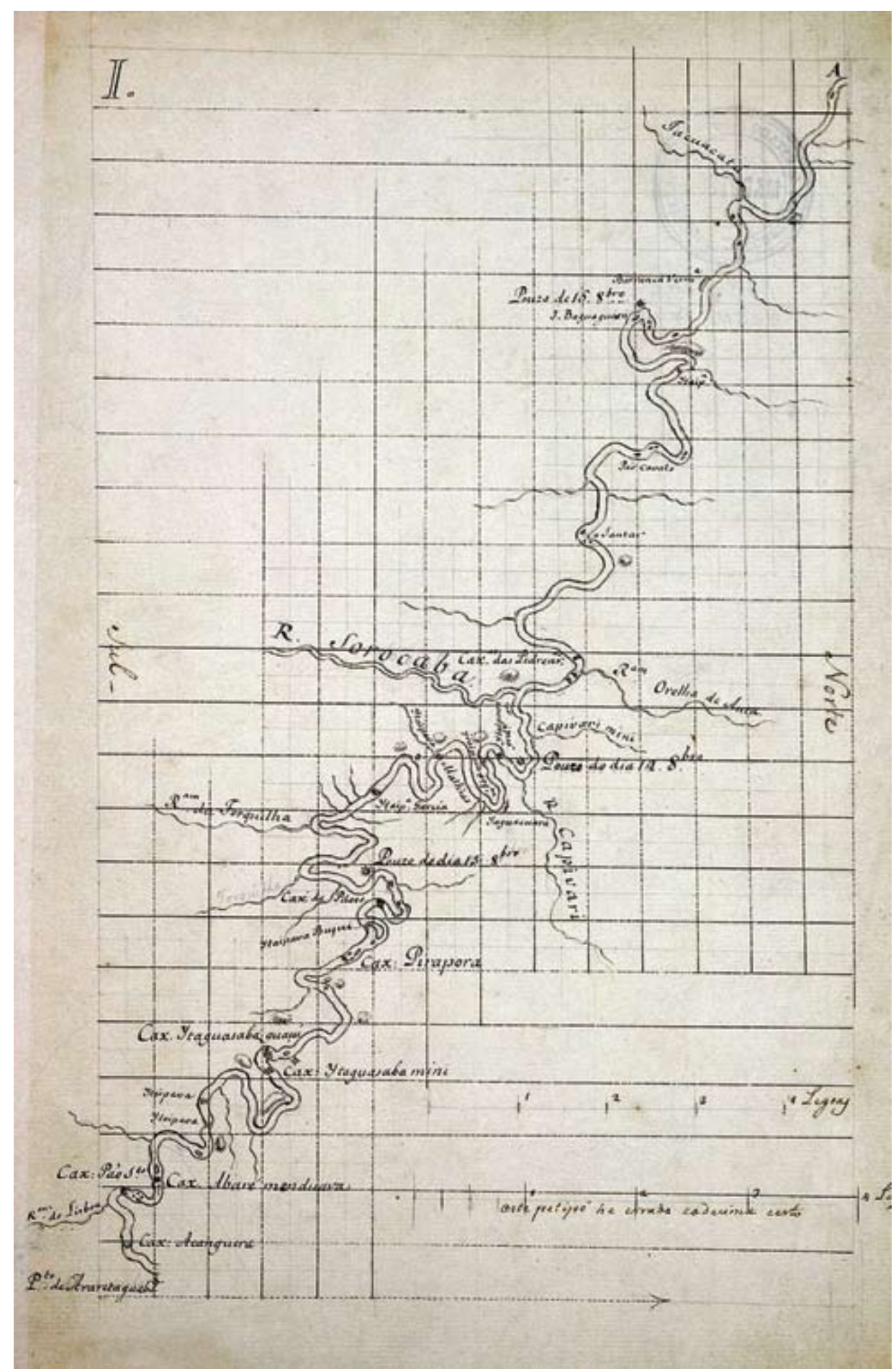

Figura 19 - A "2a. Redução" a uma escala gráfica. In: 12 Planos dos Rios do Tiete e Paraná até o Salto Grande das Sete Quedas. 2 "Redução". Autor: Engenheiro José Custódio de Sá e Faria. Dimensão: 35,0 × $22 \mathrm{~cm}$. Mapoteca do Itamaraty - Rio de Janeiro. Fotografia de Vicente de Mello. 


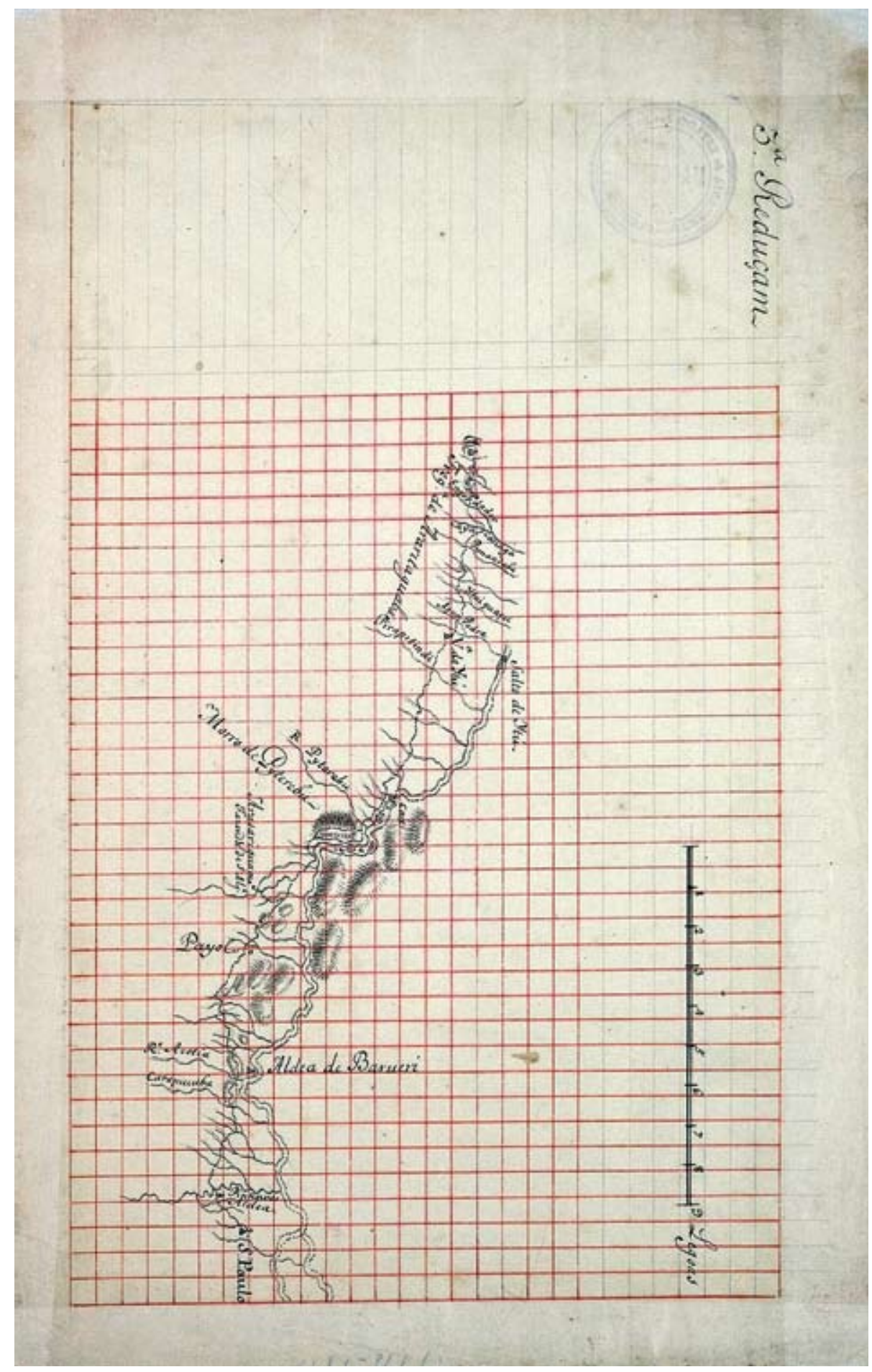

Figura 20 - A "3a. Redução" a uma escala gráfica. In: "3 ${ }^{a}$ Redução". Autor: Engenheiro José Custódio de Sá e Faria. Dimensão: 35,0 × 22 cm. Mapoteca do Itamaraty - Rio de Janeiro. Fotografia de Vicente de Mello. 
51. Devemos a D. João V uma das iniciativas mais interessantes de desenvolvimento da ciência cartográfica em solos portugueses. Dela Pombal e D. Maria foram meros herdeiros. O Observatório Astronômico da Universidade de Coimbra - criado na Faculdade de Matemática, no âmbito da Reforma Pombalina do Ensino, realizada em 1772 -, bem como a Academia de Ciências de Lisboa criada no Reinado de D. Maria I, em 1779 - decorreram
Domínios Ultramarinos, Martinho de Mello e Castro, com os mapas definitivos devidamente aquarelados (Figuras 21-26).

Do campo ao gabinete, do "borrão" às "aguadas" (aquarelamento dos mapas), havia inúmeras etapas de representação gráfica, que exigiam rigor, habilidade e paciência. $O$ engenheiro José Custódio de Sá e Faria legou-nos preciosa série de mapas e relatórios, fruto de inúmeras expedições de campo. Seus mapas são reconhecidos pela beleza e pelo rigor (Figura 27).

Sá e Faria foi um entre os muitos engenheiros militares formados segundo os métodos de representação cartográfica sintetizados por Manoel de Azevedo Fortes para as Academias Militares setecentistas ${ }^{51}$, baseados na mais moderna literatura francesa sobre a matéria. Os resultados, materializados nesses

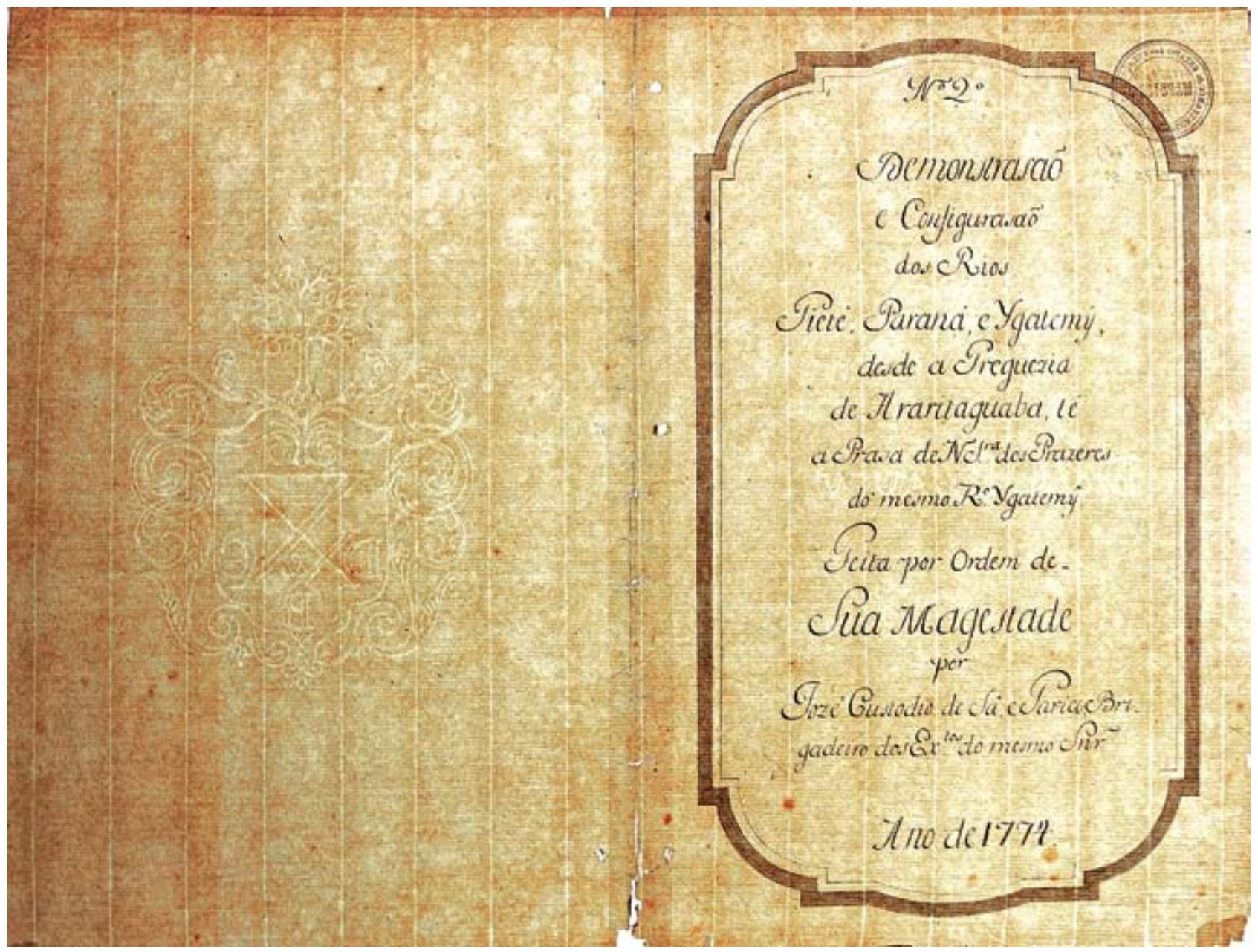

Figuras 21 a 26 - Os mapas definitivos, já aquarelados. In: "N으. Demonstração e Configuração dos rios Tietê, Paraná, e Yguatemy, desde a Freguezia de Araritaguaba, té á Prasa de N. S'a . dos Prazeres do mesmo Ro. Yguatemy. Feita por Ordem de Sua Magestade por Jozé Custodio de Sá e Faria, Brigadeiro dos Ex tos do mesmo Snr. Anno de 1774". Autor: Engenheiro José Custódio de Sá e Faria. Dimensão: 34,0 × 22,5 cm. Mapoteca do Itamaraty - Rio de Janeiro. Fotografias de Vicente de Mello. 


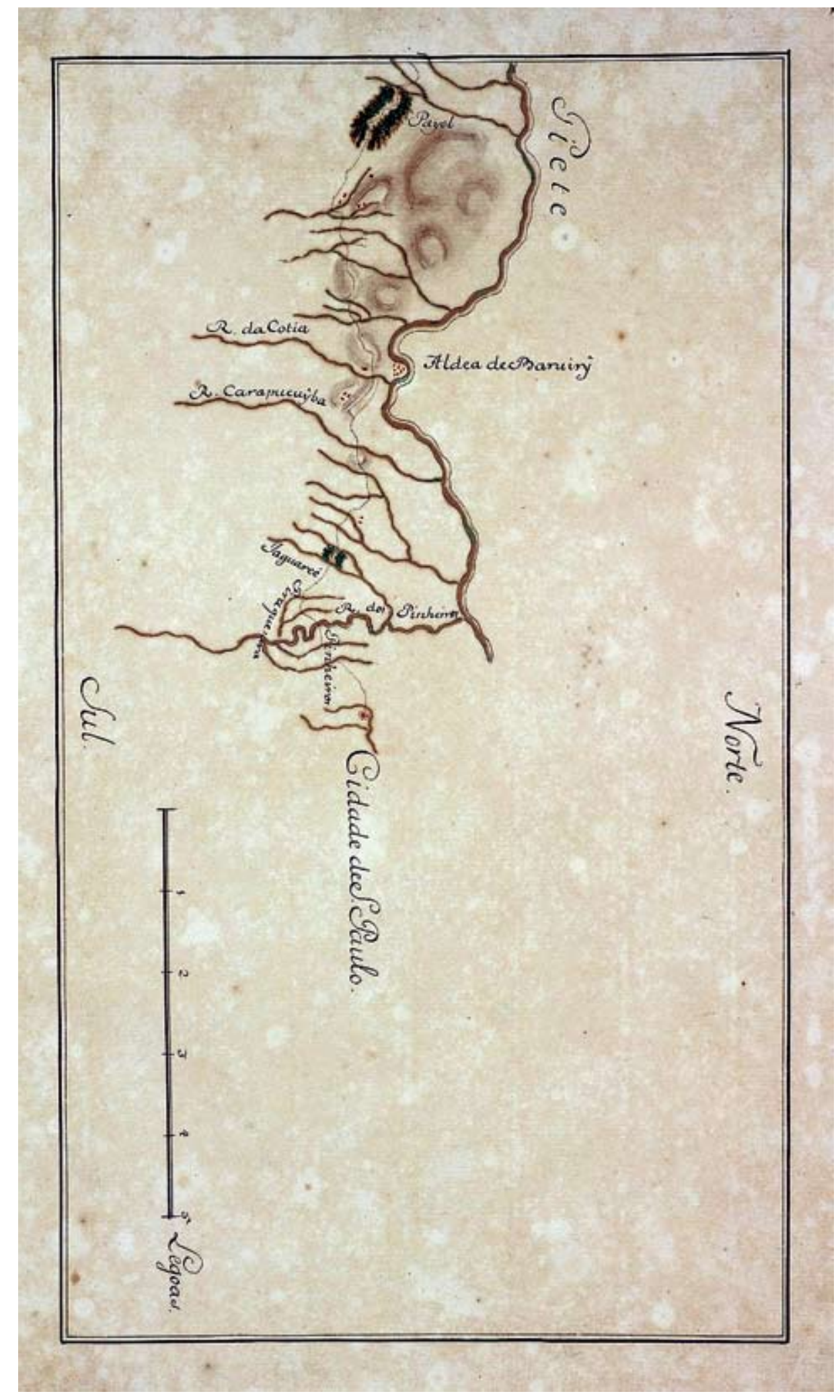




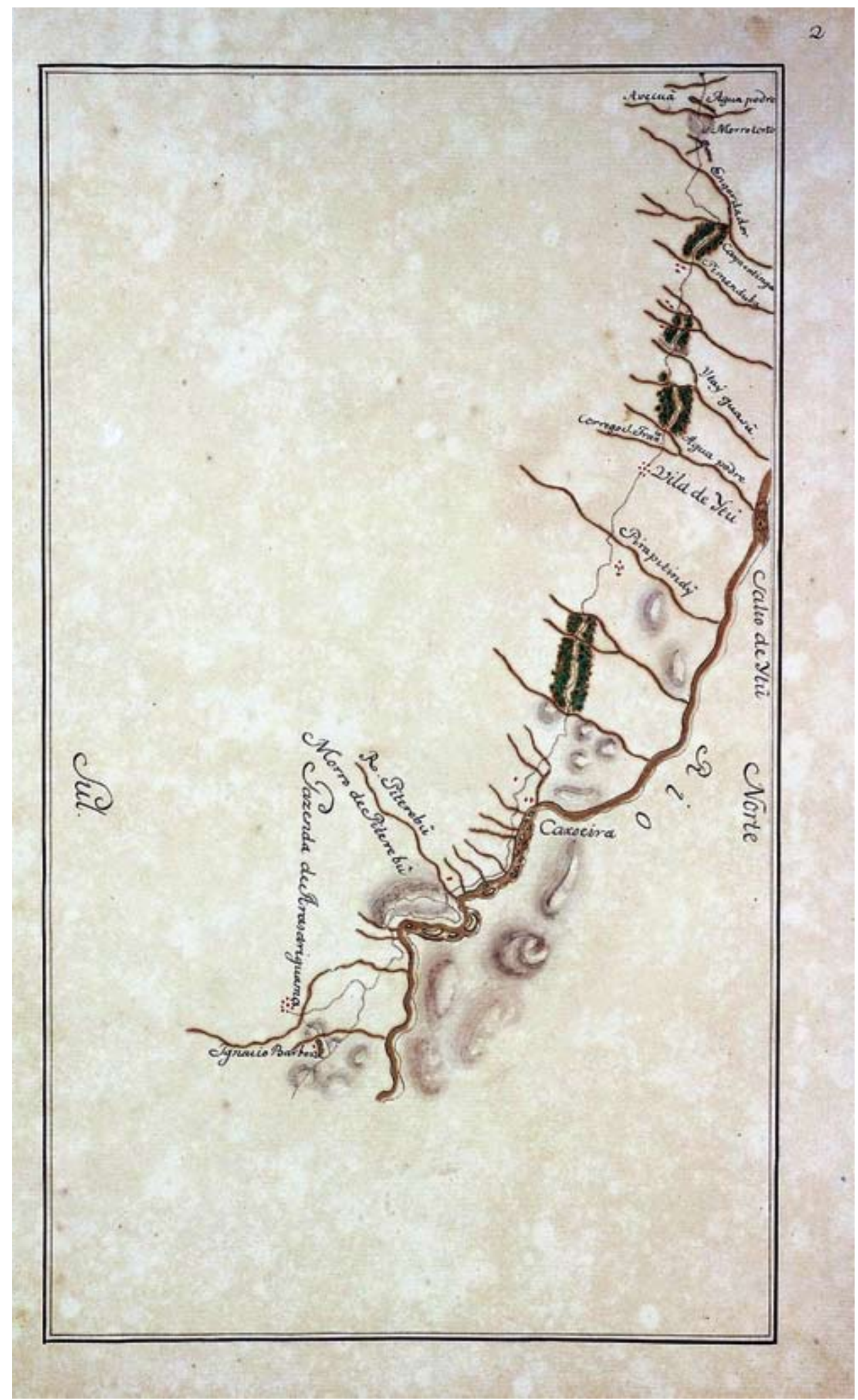




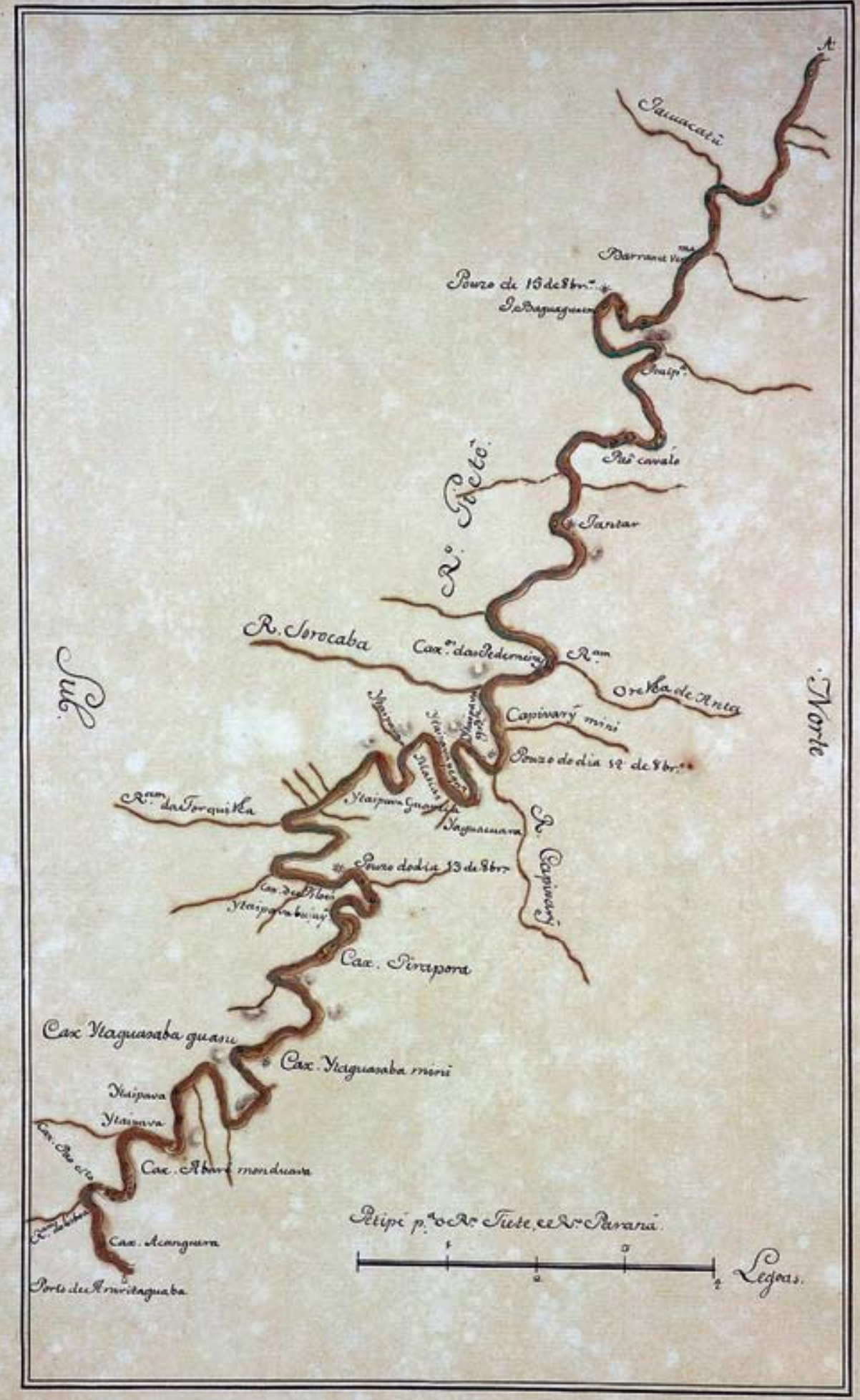



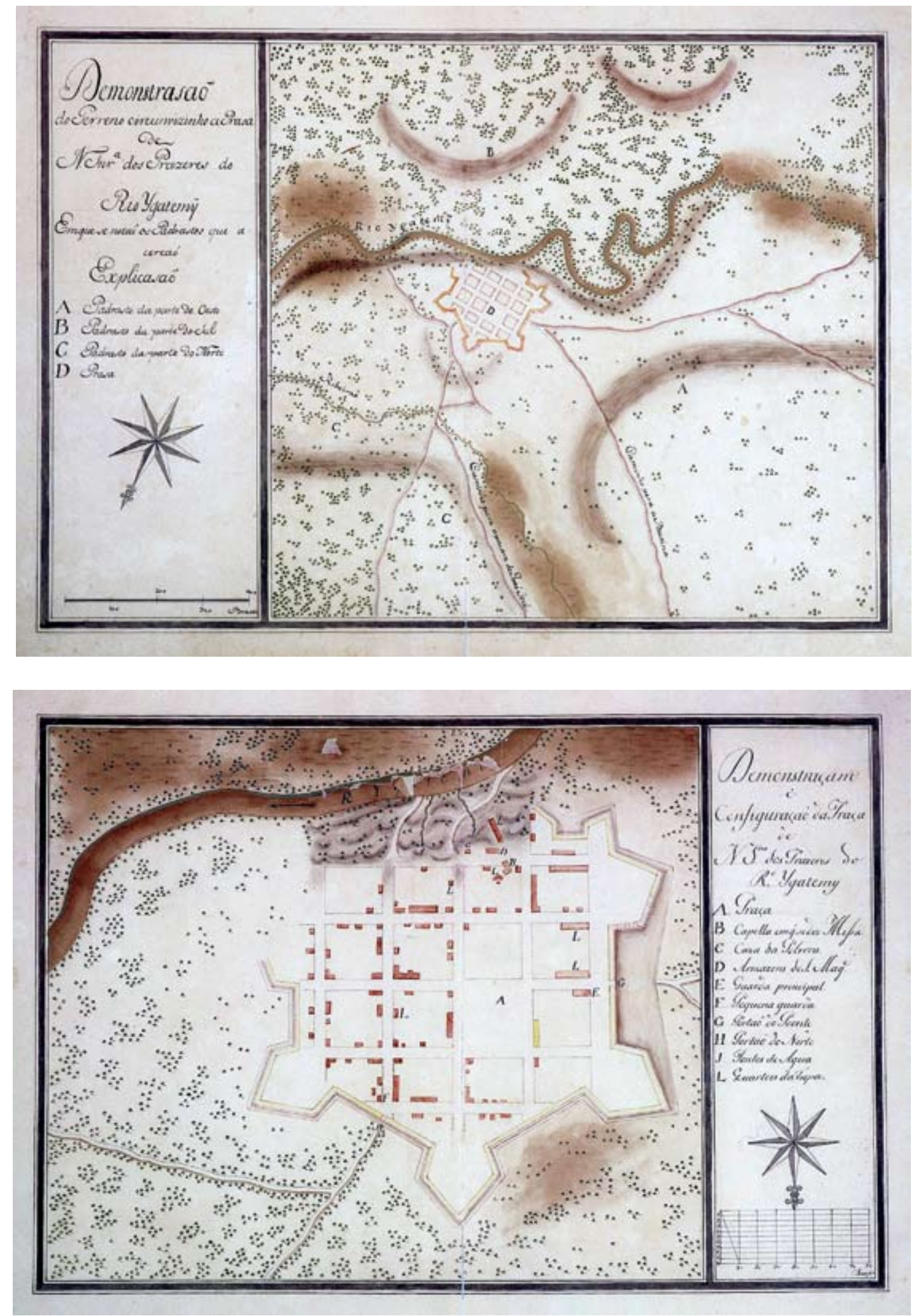


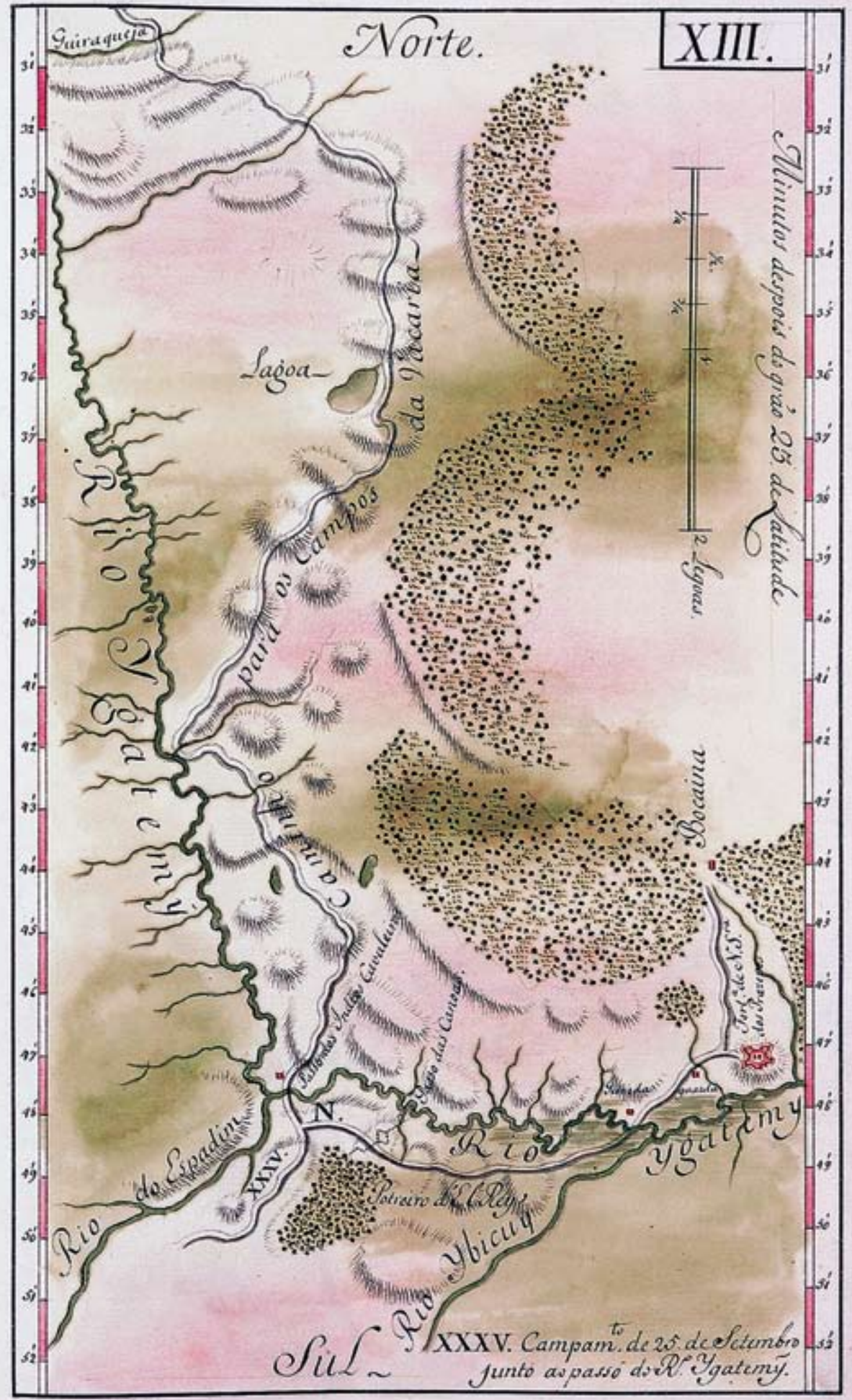

Annals of Museu Paulista. v. 17. n.2. July - Dec. 2009.
Figura 27 - Carta XIII. In: "Diário e Planos do Caminho que da cidade da Assumpção do Rio Paraguay se dirige the o passo do Rio Yguatemy, oferecidos ao III mo. e

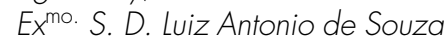
Botelho do Cons. De S. Mag. Governador \& Capam. General da Capitania de São Paulo". Autor: Engenheiro José de Custódio Sá e Faria. Data: 1754. Dimensão: $34 \times 22 \mathrm{~cm}$. Biblioteca Municipal Mário de Andrade - São Paulo. 
de estratégias políticas adotadas anteriormente. A criação da Faculdade de Matemática e do Observatório de Coimbra ocorreram 22 anos após o início da administração de Pombal, e levaram de 1772 a 1799 para se efetivar na prática. Portanto só chegaram a dar frutos no reinado de D. Maria I. A historiografia mitifica o legado pombalino em detrimento das ações modernizadoras do período joanino, só recentemente valorizadas. Consultar, a propósito: A. F. De Almeida (2001), L. M. Bernardo (2005) e M. G. Fernandes (2006).

52. Ver Manoel de Azevedo Fortes (1728-1729), especialmente o Tomo I, sobre a geometria prática no terreno e no papel.

53. Ver B. P. S. Bueno (2004). belíssimos mapas e relatórios, são a prova concreta do sucesso de uma iniciativa pedagógica, fruto de desígnios político-estratégicos de definição e controle de territórios, no centro-sul da América Portuguesa, em pleno século XVIII.

Com base no tratado $\bigcirc$ Engenheiro Português, de Manoel de Azevedo Fortes ${ }^{52}$, é possível imaginar como seria a metodologia - em campo e no gabinete - de feitura dos mapas no século XVIII. Em artigo publicado nos Anais do Museu Paulista, em 200453, apresentamos, em detalhes, os procedimentos utilizados na feitura dos mapas (instrumentos de desenho, convenções e códigos de representação, técnicas de preparo dos pigmentos e tintas, bem como aquelas utilizadas no aquarelamento das cartas), que não cabe repetir aqui.

A cartografia após o Tratado de Santo Ildefonso (1777)

De mesmo perfil e qualidade técnica é a geração de engenheiros-cartógrafos que ałuaram na Capitania de São Paulo após a assinatura do Tratado de Santo Ildefonso (1777), sobretudo no período da administração do Governador Bernardo José de Lorena: João da Costa Ferreira e Antonio Rodrigues Montezinhos.

João da Costa Ferreira nasceu em Lisboa, em 1750. Completou o curso de matemática da Real Academia Militar e, assim como José Custódio de Sá e Faria, destacou-se entre os engenheiros enviados ao Brasil com o objetivo inicial de participar de atividades demarcatórias. $\bigcirc$ brigadeiro João da Costa Ferreira deu extensa contribuição em obras de real significado para a Capitania de São Paulo. Com destino a São Paulo, veio ao Brasil ainda como capitão, em companhia de Bernardo Lorena, no reinado de D. Maria I, sendo nomeado para servir nas demarcações dos limites com os domínios da Espanha. Tendo sido paralisada essa diligência, o capitão fixou-se em solos paulistas desde 1788, sendo logo empregado em obras públicas, como por exemplo a construção da estrada que ligaria São Paulo a Cubatão, a Calçada do Lorena, empreendimento realizado para viabilizar o escoamento do açúcar então produzido em larga escala no planalto.

Típica tarefa de um engenheiro do Século das Luzes, foi também incumbido, em 1791, do levantamento das Cartas Corographicas e Hydrographicas De toda a costa, e Portos da Capitania de São Paulo. Este importante relatório, hoje na Sociedade de Geografia de Lisboa, documenta, com latitudes e longitudes observadas, todas as vilas litorâneas - Paranaguá, Guaratuba, Iguape, Cananeia, Itanhaém, Santos, Ubatuba, São Sebastião -, portos, bacias, rios com nascente na serra Geral e recursos em madeira de construção, indicando aquelas destinadas aos "cortes reais". Além dos trabalhos cartográficos e de infraestrutura territorial, atuou ainda como arquiteto civil, realizando projetos para dois novos edifícios oficiais da cidade de São Paulo: 
- Quartel da Legião de Voluntários Reais, em 1790, e o Hospital Militar da Capitania de S. Paulo 54, em c. 1805. No Brasil, pertencia ao Real Corpo de Engenheiros, tendo sido promovido do posto de sargento-mor até o de brigadeiro. Para executar sua extensa obra, João da Costa Ferreira contou com excelentes auxiliares, como o engenheiro Antonio Rodrigues Montezinhos e os matemáticos-astrônomos Francisco de Oliveira Barbosa e Bento Sanches d'Orta.

engenheiro Antonio Rodrigues Montezinhos 55 foi dos mais destacados alunos da Aula do Regimento de Artilharia do Rio de Janeiro, c. 1774. Trabalhou inicialmente na Capitania do Rio de Janeiro e depois em São Paulo, integrando - Real Corpo de Engenheiros. Entre os serviços de sua autoria, destaca-se o Mapa Corographico da Capitania de S. Paulo56, levantado por ordem de Bernardo José de Lorena, com base nos dados recolhidos em 1791 e 1792. $O$ mapa de Montezinhos é o mais minucioso de todos os mencionados até aqui, representando em detalhes a rede de caminhos, capelas, freguesias, vilas e cidades que articulava a Capitania de São Paulo às adjacentes. Trata-se do primeiro mapa geral da Capitania de São Paulo e representa com precisão seus contornos dilatados e fronteiras com as capitanias vizinhas, completando o minucioso levantamento litorâneo, com latitudes e longitudes observadas, encabeçado por João da Costa Ferreira. Põe fim a uma série de discussões sobre os limites entre as capitanias de São Paulo e Minas Gerais, que dera ensejo a ampla produção cartográfica, da qual se destacam a Carta Chorografica da Capitania de S. Paulo em que se mostra a verdadeira cituação dos lugares por onde se fizerão as sete principaes divisões do seu Governo com o de Minas Geraes $(1766)^{57}$ e - Mappa da Capitania de S. Paulo em que se mostra tudo o que ella tinha antigamente thé o Rio Paná [Paraná] (1773)58. Embora o Mapa Corographico da Capitania de S. Paulo de Montezinhos seja de grande formato, surpreende-nos a qualidade e quantidade de informações ali registradas. A escala gráfica empregada permite visualizar que a rede urbana da Capitania de São Paulo irradiava-se em todas as direções (Figura 28).

No século XVIII e primeiras décadas do XIX, além dos personagens supracitados, outros se destacam. Trata-se de profissionais que se envolveram com trabalhos de construção e mapeamento, embora pouco se conheça sobre a sua formação sistemática e trajetória como engenheiro militar. Destes, vale a pena recordar Afonso Botelho de Sampaio ${ }^{59}$, Cândido Xavier de Almeida e Souza, Manuel Angelo Figueira de Aguiar, sargento João Baptista, Antonio Ferreira Rocha, José Ruiz de Oliveira, José Corrêa Rangel de Bulhões, Manoel Martins do Couto Reis, Antonio Manoel de Melo, Antônio Elzeário de Miranda e Brito, José Antônio Teixeira Cabral, além dos consagrados, Francisco Tosi Colombina, Manoel Vieira Leão, Francisco José Lacerda de Almeida, Rufino José Felizardo e Costa, Daniel Pedro Muller, José Jacques da Costa Ourique e os matemáticos-astrônomos Francisco de Oliveira Barbosa e Bento Sanches d'Orta, homens que realizaram extensa e variada obra cartográfica, merecedora de estudos futuros ${ }^{60}$.

Este ensaio preliminar sobre a produção cartográfica dos engenheiros
54. Consultar: Planta dos novos quartéis da Legião de Voluntarios $R^{\text {es }}$ de S. Paulo (1790); Planta iconografica dos novos quartéis da Legião de Voluntarios Reaes de S. Paulo (1790); Prospecto dos Quartéis Novos da Legiam de Voluntarios Reais de S. Paulo - Anno 1790; Planta do Hospital Militar da Capitania de S. Paulo (1805). Originais pertencentes ao Arquivo Histórico do Exército - Rio de Janeiro e ao Arquivo Histórico Ultramarino - Lisboa. Ver N. G. Reis Filho (2003, p. 36 e 39) e J. J. Arruda (2000, p. 44).

55. Ver F. de S. Viterbo (1988); e, também, Aurelio Lyra Tavares (1965).

56. Está na Mapoteca do Itamaraty, no Rio de Janeiro. Consultar I. Adonias (1960).

57. Ver N. G. Reis Filho (2003, p. 49).

58. Ver J. J. Arruda (2000, p. 32).

59. A. M. Belluzzo (2003).

60. Boa parte dos seus desenhos integram as coleções da Biblioteca Nacional do Rio de Janeiro e do Arquivo Histórico do Exército-RJ. Ver N. G. Reis Filho (2003). 


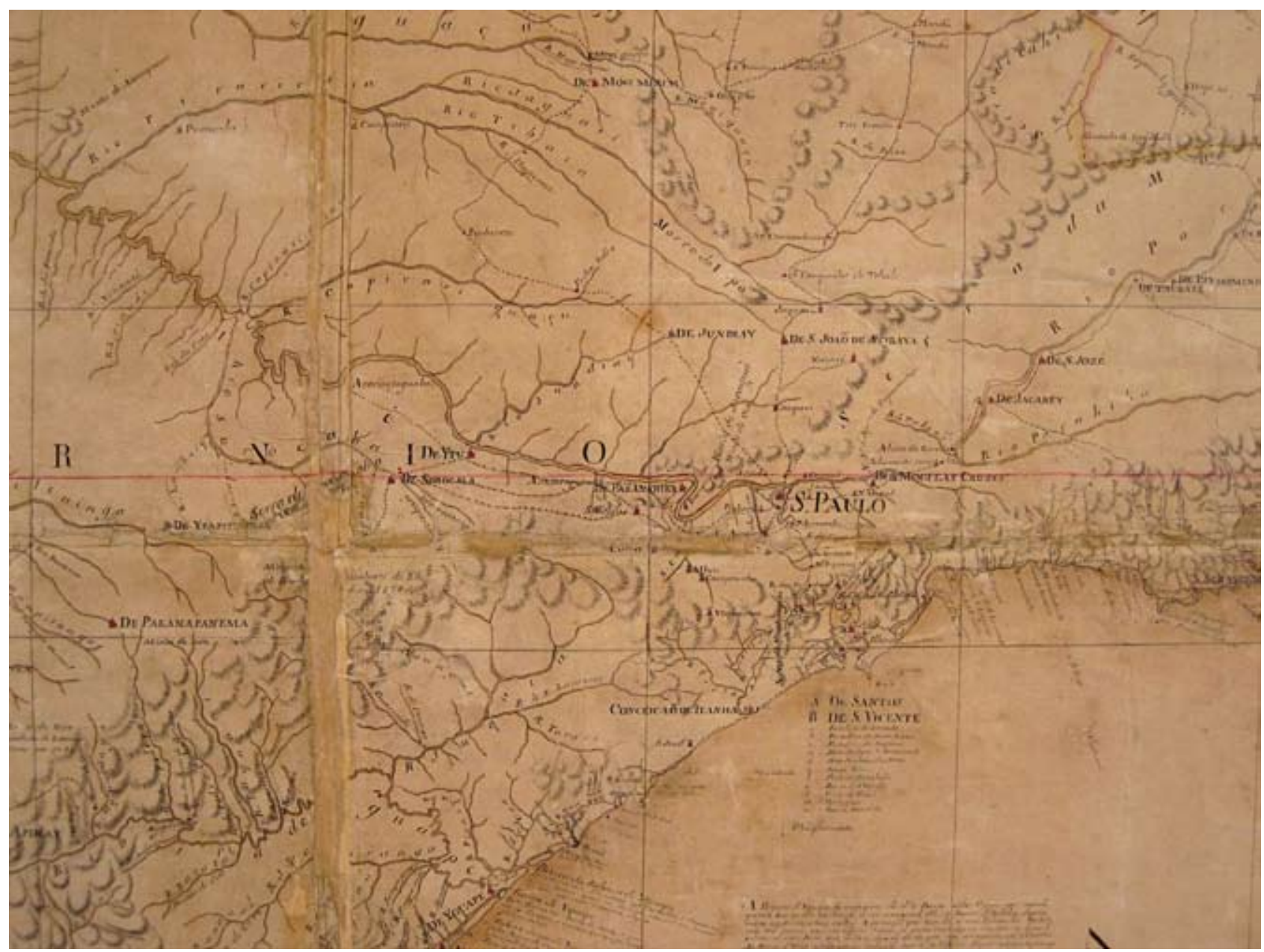

Figura 28 - Detalhe do "Mapa Corographico da Capitania de S. Paulo". Autor: Antonio Rodrigues Montezinhos. Data: 1791 e 1792. Mapoteca do Itamaraty - RJ. Fotografia de Vicente de Mello.

61. Acerca dos conceitos, consultar R. Bluteau (1712); e B. P. S. Bueno (2003, p. 482-487).

62. A propósito, ver outro artigo da autora no presente dossiê - Dilatação dos confins: caminhos, vilas e cidades na formação da Capitania de São Paulo (1532-1822). militares da Capitania de São Paulo atesta uma tese central: sua presença ou ausência sempre foi sinônimo de interesse e projeto colonizador mais ou menos dirigido. Os engenheiros aqui enviados o foram em situações estratégicas e momentos chave da história da Capitania. Ao sabor das lógicas do sistema colonial, São Paulo mereceu mais ou menos investimentos materiais e registros cartográficos. $\bigcirc$ estudo desta série documental evidencia um lento processo de dilatação de fronteiras e conversão de "sertões" em "territórios'ol colonizados pela Coroa portuguesa ${ }^{62}$. Os desenhos correspondem a projetos ou consolidam resultados destes. Nesse sentido, são ao mesmo tempo produtos e vetores de uma ação colonizadora. 


\section{REFERÊNCIAS}

ADONIAS, I. Mapas e planos manuscritos relativos ao Brasil colonial. Conservados no Ministério das Relações Exteriores e descritos por Isa Adonias para as Comemorações do V Centenário da Morte do Infante Dom Henrique. Rio de Janeiro: Ministério das Relações Exteriores, 1960.

ALMEIDA, A. F. de. Os jesuítas matemáticos e os mapas da América portuguesa (1720-1748). Oceanos, Lisboa: CNCDP, 40, p. 79-92, out.-dez.- 1999.

. A formação do espaço brasileiro e o projecto do Novo Atlas da América Portuguesa (1713-1748). Lisboa: CNCDP, 2001.

ARRUDA, J. J. de A. (coord.). Documentos manuscritos avulsos da Capitania de São Paulo. Catálogo 1 (1644-1830). São Paulo: Imprensa Oficial/ FAPESP/ EDUSC, 2000. p. 18 e 22-23.

BELLOTTO, H. L. Autoridade e conflito no Brasil colonial: o governo do Morgado de Mateus em São Paulo. São Paulo: Secretaria de Estado da Cultura, 1979.

BELLUZZO, A. M. Do contato ao confronto. A conquista de Guarapuava no século XVIII. São Paulo: BNP Paribas, 2003.

BERNARDO, L. M. O projecto cultural de Manuel de Azevedo Fortes. Um caso de recepção do cartesianismo na ilustração portuguesa. Lisboa: Imprensa Nacional - Casa da Moeda, 2005.

BLUTEAU, R. Vocabulario portuguez e latino.... Coimbra: Collegio das Artes da Companhia de Jesus, 1712.

BUENO, B. P. S. Desenbo e desígnio: o Brasil dos engenbeiros militares (1500-1822). 2001. Tese (Doutorado) - Faculdade de Arquitetura e Urbanismo, Universidade de São Paulo, São Paulo, 2001 (consultar versão revisada em 2003).

. "Desenhar" (projetar) em Portugal e Brasil nos séculos XVI-XVIII. Cadernos de Pesquisa do LAP, São Paulo, 36, jul-dez. 2002.

Decifrando mapas: sobre o conceito de "território" e suas vinculações com a cartografia". Anais do Museu Paulista - História e Cultura Material, São Paulo, v. 12. p. 193-234. jan/dez. 2004.

O engenheiro artista: as aquarelas e as tintas nos mapas do Novo Mundo. In: FURTADO, J. (org.). Sons, formas, cores e movimentos na modernidade atlântica: Europa, Américas e África. São Paulo: Annablume, 2008. p. 375-383.

Cartografia militar no Brasil do século XVIII. Do borrão às aguadas: o engenheiro cientista $\mathrm{e}$ artista. In: DIAS, M. H. et al. História da Cartografia Militar (Séculos XVIII-XIX). Viana do Castelo: Câmara Municipal de Viana do Castelo, 2006. p. 21-45.

Desenhando o Brasil: o saber cartográfico dos cosmógrafos e engenheiros militares da América Portuguesa e do Brasil Império. In: COSTA, A G. (org.). Roteiro prático de cartografia: da América Portuguesa ao Brasil Império. Belo Horizonte: UFMG, 2007. p. 29-49. 
BUENO, B. P. S. Entre teoria e prática: a cartografia dos engenheiros militares em Portugal e no Brasil (séculos XVI-XVIII). Terra Brasilis - Revista de História do Pensamento Geográfico no Brasil, Rio de Janeiro, Ano VI-VII-VIII, ns. 7-8-9, p.60-96, 2005-2007.

CÁMARA, A. Fortificación y ciudad em los reinos de Felipe II. Madrid: NEREA, 1998.

CORTESÃO, J. Alexandre de Gusmão e o Tratado de Madrid. Lisboa: Livros Horizonte, 1984.

Descripção de todo o Maritimo da Terra de S. Crus chamado vulgarmente o Brazil [c.1640]. [Textos transcritos com a grafia original do Atlas...]. São Paulo: Pinacoteca do Estado/ Coleção Brasiliana/ Fundação Estudar, 2003. Edição facsimilar.

FARIA, J. C. S. [Diário e mapas das viagens de José Custódio de Sá e Faria, da Cidade de São Paulo até o Presídio de $\mathrm{N}^{\text {a }} \mathrm{S}{ }^{\text {a }}$ dos Prazeres, no rio Iguatemi, e da mesma Cidade de até a Vila de Paranaguá, nos anos de 1774 a 1776]. Mapoteca do Itamaraty, Rio de Janeiro.

34 Planos do Rio do Tietê desde o porto de Araritaguaba, e Paraná até o Iguatemi, em esboço. Mapoteca do Itamaraty, Rio de Janeiro.

12 Planos dos Rios do Tiete e Paraná até o Salto Grande das Sete Quedas. $2{ }^{a}$ Redução. Mapoteca do Itamaraty, Rio de Janeiro.

$3{ }^{a}$ Redução. Mapoteca do Itamaraty, Rio de Janeiro.

. Diário da Viagem que fes o Brigadeiro José Custódio de Sá e Faria desde a Cidade de S. Paulo até a Praça de N. Sra. Dos Prazeres do Ro. Ygatemi por Ordem de Sua Magestade, 31 de janeiro de 1775. Coleção Duarte da Ponte Ribeiro do Arquivo Histórico do Itamaraty, Rio de Janeiro.

Diário da viagem que fez o brigadeiro José Custódio de Sá e Faria da Cidade de São Paulo à praça de Nossa Senbora dos Prazeres do rio Iguatemy 1774-1775. Revista do Instituto Histórico, Geographico e Ethnographico do Brasil, Rio de Janeiro, v. 39, p. 217-278, 1876.

FERNANDES, M. G. (coord.). Manoel de Azevedo Fortes (1660-1749). Cartografia, cultura e urbanismo. Porto: GEDES/ Departamento de Geografia da Faculdade de Letras da Universidade do Porto, 2006.

FORTES, M. A. O engenbeiro português. Lisboa: Oficina de Manoel Fernandes da Costa, 1728-1729.

HARLEY, J. B. La nueva naturaleza de los mapas. Ensayos sobre la historia de la cartografia. México: Fondo de Cultura Económica, 2005.

KOK, G. O sertão itinerante. Expedições da Capitania de São Paulo no século XVIII. São Paulo: Hucitec/FAPESP, 2004.

MORA-FIGUEROA, D. Las Relaciones Topográficas de Castilla y Geográficas de Indias de Felipe II. In: TASCÓN, I. G. (org). Felipe II: Los ingenios y las maquinas. Ingeniería y obras públicas en la época de Felipe II. Madrid: Sociedad Estatal para la Comemoración de los Centenarios de Felipe II Y Carlos V, 1998.

MOREIRA, R. O engenheiro-mór e a circulação das formas no império português. In: Portugal $e$ Flandres. Visões da Europa (1550-1680). Lisboa: Instituto Português do Patrimônio Cultural/ Mosteiro dos Jerónimos, 1992. p. 97-107. 
MORI, V. H.; LEMOS. C.; CASTRO, A H. F. de. Arquitetura militar. Um panorama a partir do Porto de Santos. São Paulo: Imprensa Oficial do Estado/ Fundação Cultural Exército Brasileiro, 2003.

PANOFSKY, E. Iconografia e iconologia: uma introdução ao estudo da Arte da Renascença. In: Significado nas Artes Visuais. São Paulo: Perspectiva, 1979. p. 45-88.

PEREDA, F.; MARÍAS, F. (eds.). El Atlas del Rey Planeta. "La Descripción de Espanã y de las costas y puertos de sus reinos" de Pedro Teixeira (1634). San Sebastian: NEREA, 2007.

REIS FILHO, N. G. Imagens das vilas e cidades do Brasil colonial. [Colaboradores: Beatriz P. S. Bueno e Paulo J. V. Bruna]. São Paulo: EDUSP/ Imprensa Oficial do Estado/ FAPESP, 2000.

. Leituras cartográficas históricas e Contemporâneas. São Paulo: MAC-USP/ Brasil Connects/ Fundação Cultural Exército Brasileiro/ DAC/ AHEX, 2003.

São Paulo: vila, cidade e metrópole. São Paulo: Bank Boston, 2004.

RUSSELL-WOOD, A. J. R. The portuguese empire (1415-1808). A world on the move. Baltimore and London: The Johns Hopkins University Press, 1998.

SOROMENHO, M. Diogo de Campos Moreno [verbete] In: Portugal e Flandres. Visões da Europa (1550-1680). Lisboa: Instituto Português do Patrimônio Cultural/ Mosteiro dos Jerónimos, 1992. p. 202-203,

SOUZA, J. S. de; MAKINO, M. (orgs.). Diário da navegação. Teotônio José Juzarte. São Paulo: EDUSP, 2000.

TAVARES, Aurelio Lyra. A engenharia militar portuguesa na construção do Brasil. Rio de Janeiro: Estado-Maior do Exército, 1965.

TOLEDO, B. L. O Real Corpo de Engenheiros da Capitania de São Paulo. Tese (Doutorado), Faculdade de Arquitetura e Urbanismo da USP, São Paulo, 1972.

VITERBO, F. De S. Expedições Científico-Militares Enviadas ao Brasil [Coordenação, Aditamentos e Introdução de Jorge Faro]. Lisboa, Edições Panorama, 1962, vols. 1-2.

VITERBO, Francisco de Sousa. Dicionário Histórico e Documental dos Architectos, Engenheiros e Construtores Portugueses. Lisboa, Imprensa Nacional-Casa da Moeda, 1988, vols. 1-3.

Artigo apresentado em 8/2008. Aprovado em 3/2009.

Annals of Museu Paulista. v. 17. n.2. July - Dec. 2009. 